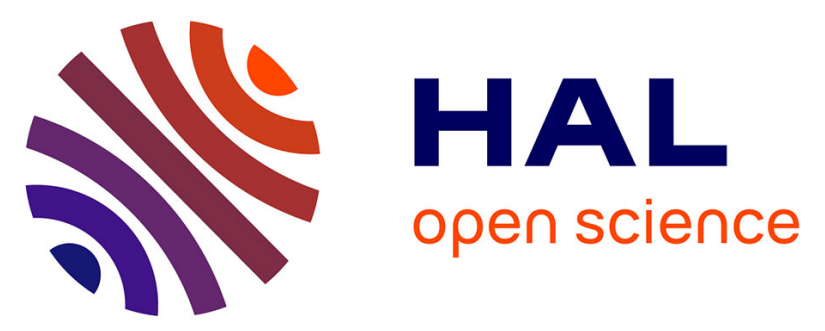

\title{
IMPACT OF IMPURITIES ON CO 2 STORAGE IN SALINE AQUIFERS: MODELLING OF GASES SOLUBILITY IN WATER
}

Martha Hajiw, Jérôme Corvisier, Elise El Ahmar, Christophe Coquelet

\section{- To cite this version:}

Martha Hajiw, Jérôme Corvisier, Elise El Ahmar, Christophe Coquelet. IMPACT OF IMPURITIES ON CO 2 STORAGE IN SALINE AQUIFERS: MODELLING OF GASES SOLUBILITY IN WATER. International Journal of Greenhouse Gas Control, inPress. hal-01678837

\section{HAL Id: hal-01678837}

https://hal-mines-paristech.archives-ouvertes.fr/hal-01678837

Submitted on 9 Jan 2018

HAL is a multi-disciplinary open access archive for the deposit and dissemination of scientific research documents, whether they are published or not. The documents may come from teaching and research institutions in France or abroad, or from public or private research centers.
L'archive ouverte pluridisciplinaire HAL, est destinée au dépôt et à la diffusion de documents scientifiques de niveau recherche, publiés ou non, émanant des établissements d'enseignement et de recherche français ou étrangers, des laboratoires publics ou privés. 


\title{
IMPACT OF IMPURITIES ON $\mathrm{CO}_{2}$ STORAGE IN SALINE AQUIFERS: MODELLING OF GASES SOLUBILITY IN WATER
}

\author{
Martha Hajiw $^{\mathrm{a}, \mathrm{b}}$, Jérôme Corvisier ${ }^{\mathrm{b}^{*}}$, Elise El Ahmar ${ }^{\mathrm{a}}$, Christophe Coquelet ${ }^{\mathrm{a}}$ \\ ${ }^{a}$ Mines ParisTech, PSL Research University, Centre Thermodynamics of Processes, 35 rue Saint Honoré, 77305 \\ Fontainebleau Cedex, France \\ ${ }^{\mathrm{b}}$ Mines ParisTech, PSL Research University, Centre de Géosciences, 35 rue Saint Honoré, 77305 Fontainebleau \\ Cedex, France
}

Flue gas captured contains different impurities $\left(\mathrm{N}_{2}, \mathrm{O}_{2}, \mathrm{SO}_{2}, \mathrm{NO}\right.$ etc) and their concentrations depend on the capture process and the industrial sector. Moreover, the presence of impurities may change the thermophysical properties of the stream and therefore impact the conditions of $\mathrm{CO}_{2}$ storage. The aim of the paper is to investigate the solubility in water of carbon dioxide and some chosen impurities. In this work VLE calculations using a geochemical model (Corvisier, 2013) and two group contribution (GC-PR-CPA (Group Contribution-Peng Robinson-Cubic Plus Association) (Hajiw, 2014 and Hajiw et al., 2015) and E-PPR78 (Qian et al., 2013) equations of state) models are compared.

Keywords: Water/gas solubility; $\mathrm{CO}_{2}$; Co-injected impurities; Group contribution method

\footnotetext{
* Corresponding author:

E-mail: jerome.corvisier@mines-paristech.fr Telephone: +33 (0) 164694750

Christophe.coquelet@mines-paristech.fr tel: +33(0) 164694962
} 


\section{INTRODUCTION}

Combustion of fossil fuels and industrial processes are the principal anthropological sources of greenhouse gases emissions (carbon dioxide, methane, NOx, SOx...) to the atmosphere.

Emissions of carbon dioxide, estimated at 35 gigatons in 2013 (Agency P.N.E.A., 2014), are considered to be the major cause of global warming. Carbon Capture and Storage (CCS) is a solution proposed to avoid emissions of carbon dioxide. Conditions for $\mathrm{CO}_{2}$ storage are considered to be in this study in the temperature and pressure range of $300-423 \mathrm{~K}$ and 6-30 MPa (Liebscher et al., 2013).

Depending on the capture process and the industrial field, the flue gases contain different impurities, with various compositions. Three examples, from a thermal power plant (Case A), a cement plant (Case B) (Meunier et al., 2014) and a coal IGCC (Integrated Gasification Combined Cycle) plant (Case C) (European Communities, 2011) are presented in Table 1. In all plants, coal is used as the major fuel.

\section{[Table 1]}

In this study, the major focus is the solubility of these impurities in water. Indeed, their presence in the flue gas may change $\mathrm{CO}_{2}$ thermophysical properties (density, viscosity) and phase diagram behaviour (solubility). As an example of the effect of different impurities on phase diagrams, phase envelopes of pure $\mathrm{CO}_{2}$ and mixtures given in Table 1 are drawn on Figure 1.

[figure 1]

Depending on the binary system, there are more or less data (Table 2). To the knowledge of the authors, no experimental data has been found for VLE of $\mathrm{NO}-\mathrm{H}_{2} \mathrm{O}$ and $\mathrm{NO}_{2}-\mathrm{H}_{2} \mathrm{O}$ under pressure. On the contrary, VLE data are abundant for $\mathrm{CO}_{2}-\mathrm{H}_{2} \mathrm{O}, \mathrm{N}_{2}-\mathrm{H}_{2} \mathrm{O}$ and $\mathrm{CH}_{4}-\mathrm{H}_{2} \mathrm{O}$ systems. References for these systems are presented in Table 2.

[Table 2] 
To predict phase diagrams, it is necessary to have robust models. In this paper, three models are applied and compared on binary systems: two group contribution models (GC-PR-CPA (Hajiw et al., 2015) and E-PPR78 (Qian et al., 2013) EoS or equations of state) and a geochemical model (Corvisier, 2013). All three models have the Peng-Robinson EoS (Peng and Robinson, 1976) in common. Few data have been found in the open literature for ternary systems with water. Therefore, only three systems (i.e. two ternary systems $\mathrm{CO}_{2}-\mathrm{CH}_{4}-\mathrm{H}_{2} \mathrm{O}$ and $\mathrm{CO}_{2}-\mathrm{N}_{2}-\mathrm{H}_{2} \mathrm{O}$ and a quaternary $\mathrm{CO}_{2}-\mathrm{CH}_{4}-\mathrm{H}_{2} \mathrm{~S}-\mathrm{H}_{2} \mathrm{O}$ ) are presented and used to validate all three models.

\section{THERMODYNAMIC MODELLING}

\subsection{Group Contribution Models}

In group contribution models, molecules can be divided into groups and interactions between groups are taken into account rather than between molecules (e.g. UNIFAC model (Fredenslund et al., 1975)). However, in this study, molecules of interest are small and can therefore be considered also as groups.

The PR-CPA EoS (Hajiw et al., 2015) has been used in this work. This model is composed of the cubic Peng Robinson EoS and the Wertheim term (Wertheim, 1984) which takes into account the presence of $\mathrm{H}$-bonds due to the presence of associating molecules like water (equation 1)

$$
P=\frac{R T}{v-b_{i}}-\frac{a_{i}(T)}{v\left(v+b_{i}\right)+b_{i}\left(v-b_{i}\right)}-\frac{1}{2} \frac{R T}{v}\left(1+\rho \frac{\partial \ln (g)}{\partial \rho}\right) \sum_{i=1}^{N} x_{i} \sum_{A_{i}}\left(1-X_{A_{i}}\right)
$$

The Peng-Robinson (PR) EoS is used in both E-PPR and GC-PR-CPA EoS. Therefore, when considering systems of non-associating compounds, the GC-PR-CPA EoS is reduced to the E-PPR78 EoS. Therefore, the attractive parameter $a_{i}$ and the co-volume $b_{i}$ for non-associating compounds are described by the same equations (Jaubert et al., 2014).

In E-PPR78, there are two adjustable group interaction parameters $\left(A_{k l}\right.$ and $\left.B_{k l}\right)$, that can be found in the paper of (Xu et al., 2015). As for the GC-PR-CPA EoS, different steps of adjustment have been taken into account. First, five parameters of the PR-CPA EoS (attractive 
parameter $a_{0}$, co-volume $b$, parameter $C_{l}$, association energy $\varepsilon$ and association volume $\beta$ ) have been adjusted for pure water using vapour pressure and saturated liquid density data (see thesis of Hajiw (Hajiw, 2014)). They are recalled in Table 3. Then, group interaction parameters for gases - water binary systems $\left(C_{k l}, D_{k l}\right.$ and $\left.E_{k l}\right)$ have been adjusted on solubility data (Table 2). The modified simplex algorithm has been used to minimize the objective function. They are given in Table 4. Equations used in both models are developed in the appendix.

[Table 3]

[Table 4]

\subsection{Geochemical Model}

The geochemical model presented shortly in this part is implemented in CHESS/HYTEC software (Corvisier, 2013; Corvisier et al., 2013). The dissymmetrical approach $\gamma-\varphi$ is used in geochemistry (Equation 2):

$$
m_{i}^{a q} \gamma_{i}^{a q} K_{i}^{g}\left(T, P^{s a t}\right) \exp \left(v_{i}^{\infty} \frac{P-P^{s a t}}{R T}\right)=y_{i}^{g} \varphi_{i}^{g} P
$$

where $m_{i}$ is the molality (mol/kg of water) of the dissolved gaseous component $i, \gamma_{i}^{a q}$ its activity coefficient, $K_{i}^{g}$ the Henry's law constant at water saturation pressure, $v_{i}^{\infty}$ the molar volume of the dissolved gaseous component at infinite dilution, $y_{i}^{g}$ the component mole fraction in the gas phase and $\varphi_{i}{ }^{g}$ its fugacity coefficient. For the gas phase, the PR EoS is used. Henry's law constants can be collected from various sources of the literature. Molar volumes, used to correct these latter for pressure, can be obtained from the revised Helgeson-KirkhamFlowers general equation (Tanger etal., 1988) and the associated parameters are also found in the literature.

Moreover, this last model uses an important database and could solve a large set of mass balance and mass action laws equations to calculate the whole water speciation (i.e. $\mathrm{pH}$, concentrations of species such as $\left.\mathrm{HCO}_{3}{ }^{-}, \mathrm{CO}_{3}{ }^{2-}, \mathrm{SO}_{4}{ }^{2-} \ldots\right)$ and minerals dissolution/precipitation (i.e. carbonates, cement phase...).

Parameters for pure gases and for gas solubilities are given in Table 5. In this model, binary interaction parameters are temperature independent. 


\section{[Table 5]}

\section{RESULTS AND DISCUSSION}

\subsection{Binary systems with water}

Models are compared over experimental data found in the literature for each binary system. However, availability of data is disparate according to the binary system. Deviations are presented in Table 6. Duan and co-workers (Duan et al., 2003; Duan and Mao, 2006; Duan et al., 2007; Mao and Duan, 2006; Geng and Duan, 2006) also developed a model for gas solubility in water. When it is possible, their model is compared to the other three.

[Table 6]

Deviations for the same systems for temperature/pressure conditions from 300 to $423 \mathrm{~K}$, from 6 to $60 \mathrm{MPa}$ are given in Table 7. In general, while the GC-PR-CPA EoS presents lower deviations for higher pressures, E-PPR78 and the geochemical model give similar deviations than the ones presented in Table 6. A reason is that, for the GC-PR-CPA EoS, parameters have been adjusted for high pressures. For $\mathrm{SO}_{2}$, when low and high pressures data are omitted the deviation for the GC-PR-CPA EoS decreases, whereas the deviations for others are significantly improved. The explanation comes from the fact that fitted (GC-PR-CPA and EPPR78) or collected (geochemical model) parameters of each model have been adjusted on various data temperature/pressure ranges. Consequently, it shall also be mentioned that results could be improved with adapted and optimized fit.

\section{[Table 7]}

Figures 2 and 3 present respectively $\mathrm{CO}_{2}$ and $\mathrm{SO}_{2}$ solubilities in water at three temperatures. Water content in $\mathrm{CO}_{2}$ at three isotherms is shown on Figure 4.

[Figures 2-4]

Table 8 gives deviations between experimental data and predictions for the $\mathrm{CO}_{2}-\mathrm{H}_{2} \mathrm{O}$ and $\mathrm{SO}_{2}-\mathrm{H}_{2} \mathrm{O}$ binary systems presented on Figures 2 and 4. It reveals that the quality of data is very important for estimation of deviations and evaluation of the performance of the models.

[Table 8] 
Based on Tables 6 and 7 and Figures 2 to 4, one may say that the geochemical model and the GC-PR-CPA give similar predictions for gas solubilities in water. Concerning the E-PPR78 EoS, while its predictions are in good agreement with experimental data for carbon dioxide or methane solubilities in water, it gives qualitative rather than quantitative predictions for nitrogen, oxygen and hydrogen solubilities in water. Solubilities and water contents from the geochemical model are satisfactory using literature parameters and once again, it shall be pointed out that the whole water speciation is calculated and potential minerals dissolution/precipitation reactions could also be taken into account.

\subsection{Multicomponent gas mixtures + water systems}

While fair amount of data are available for binary systems with water, limited data for ternary or multicomponent systems containing carbon dioxide, water and impurities are available in the open literature, particularly at conditions of interest. Scarce data have been found for the $\mathrm{CO}_{2}-\mathrm{CH}_{4}-\mathrm{H}_{2} \mathrm{O}$ ternary system (Qin et al., 2008; Chapoy et al., 2016; Song and Kobayashi, 1990; Dhima et al., 1999, Al Ghafri, 2014) (Figures 5 Figure 8), one reference for the $\mathrm{CO}_{2}$ $\mathrm{N}_{2}-\mathrm{H}_{2} \mathrm{O}$ system (Liu et al., 2012) (Figures 9 and 10) and the $\mathrm{CO}_{2}-\mathrm{CH}_{4}-\mathrm{H}_{2} \mathrm{~S}-\mathrm{H}_{2} \mathrm{O}$ quaternary system (Robinson et al., 1982) (Figures 11 and 12).

[Figures 5 and 12]

Deviations between experimental data and models are given in Table 9.

[Table 9]

Based on previous figures, one might observe that the presence of impurities decreases the solubility of carbon dioxide in the water rich phase.

According to Table 9, deviations for multicomponent systems are of the same order of magnitude than for binary systems. However, there are some concerns about the measurements for the $\mathrm{CO}_{2}-\mathrm{CH}_{4}-\mathrm{H}_{2} \mathrm{O}$ ternary system. Indeed, for a similar composition of the gas phase (about $50 \% \mathrm{CO}_{2}-50 \% \mathrm{CH}_{4}$ ), there are discrepancies between water content data (Figure 7). Moreover, the trend does not follow neither other data (Chapoy et al., 2016) (Figure 8) nor the one given by the PR-CPA EoS with a binary interaction parameter $k_{i j}$ set to 0. Yet, it has been shown in the paper of (Hajiw et al. 2015), that for such systems, adjusted binary interaction parameters are necessary for solubility predictions but not for water content. The modelling of the quaternary system $\mathrm{CO}_{2}-\mathrm{CH}_{4}-\mathrm{H}_{2} \mathrm{~S}-\mathrm{H}_{2} \mathrm{O}$ shows relatively good 
results regarding the experimental data (Robinson et al., 1982), and regarding another model from the literature (Zirrahi et al., 2012) as well for our three models. This last comparison tends to demonstrate the ability of these three approaches to handle complex gas mixtures.

\section{CONCLUSION}

Thermodynamic and geochemical models have been applied to binary and ternary systems with water. Compared to literature data, the geochemical model and the GC-PR-CPA Eos give satisfactory results. However, predictions are strongly dependent on the availability and quality of experimental data, and consequently on the quality of the selected parameters for the geochemical model. Solubility data for $\mathrm{SO}_{2}$ and $\mathrm{O}_{2}$ at storage conditions (higher pressures and temperatures) and solubility data for NO are missing. Very few data for multicomponent systems are available in the open literature to validate the three models.

It is noticeable that the three models are built around the same general cubic EOS (i.e. PengRobinson) using different methods (i.e. associating term, group contribution, symmetrical/dissymmetrical approach...). Nevertheless, they all demonstrate ability to deal with complex gas mixtures over relatively large temperature and pressure ranges. Providing sufficient experimental data to calibrate their associated parameters, the models are able to handle some computations involving $\mathrm{CO}_{2}$ and potential impurities within the context of its capture, transport (group contribution models) and geological storage (geochemical model).

\section{ACKNOWLEDGMENTS}

This research work is part of an ongoing project, funded by the French Agence Nationale de la Recherche (ANR) for the SIGARRR project (ANR-13-SEED-006). Its financial support is gratefully acknowledged. The authors wish to thank Dr. Antonin Chapoy for his advices concerning the use of the software Hydraflash®.

\section{List of Tables}


Table 1: Example of compositions of flue gases from thermal power plant (Case A, (Meunier et al., 2014)), a cement plant (Case B, (Meunier et al., 2014)) and a coal IGCC plant (Case C, European Communities, 2011)).

Table 2: Gas solubility data in pure water.

Table 3: PR-CPA parameters for pure water (Hajiw et al., 2015)

Table 4: Group interaction parameters (GC-PR-CPA) with water $\left(\mathrm{C}_{\mathrm{k}, \mathrm{H} 2 \mathrm{O}}, \mathrm{D}_{\mathrm{k}, \mathrm{H} 2 \mathrm{O}}\right.$ and $\left.\mathrm{E}_{\mathrm{k}, \mathrm{H} 2 \mathrm{O}}\right)$

Table 5: Sources for Henry's law constants, HKF parameters for molar volume at infinite dilution, values for critical temperature and pressure, acentric factors and fitted water binary interaction parameters.

Table 6: AAE (Absolute Average Error) and AAD (Absolute Average Deviation)) between experimental data and predictions

Table 7: AAE (Absolute Average Error) and AAD (Absolute Average Deviation)) between experimental data and predictions at limited pressure conditions

Table 8: Deviations (AAD \%) between experimental data and predictions for $\mathrm{CO}_{2}-\mathrm{H}_{2} \mathrm{O}$ and $\mathrm{SO}_{2}-\mathrm{H}_{2} \mathrm{O}$ binary systems

Table 9: Deviations (AAD \%) between experimental data and predictions for ternary systems

\section{List of Figures}

Figure 1: Pressure-Temperature diagram. Solid line: pure $\mathrm{CO}_{2}$. Broken dotted line: Case A. Dashed line: Case B. Dotted line: Case C. Grey square: storage conditions in saline aquifers.

Figure 2: $\mathrm{CO}_{2}$ solubility in water at $323 \mathrm{~K}(\bullet), 373 \mathrm{~K}(\boldsymbol{\Delta})$ and $423 \mathrm{~K}(\bullet)$ (Hou et al. 2013). Solid lines: GC-PR-CPA EoS. Dotted lines: E-PPR78 EoS. Dashed lines: geochemical model

Figure 3: $\mathrm{SO}_{2}$ solubility in water at $333 \mathrm{~K}(\bullet), 363 \mathrm{~K}(\boldsymbol{\Delta})$ and $393 \mathrm{~K}(\bullet)$ (Rumpf and Maurer, 1992). Solid lines: GC-PR-CPA EoS. Dotted lines: E-PPR78 EoS. Dashed lines: geochemical model

Figure 4: Water content at $323 \mathrm{~K}(\diamond$, (Hou et al. 2013)), $373 \mathrm{~K}(\boldsymbol{\Delta}$, (Hou et al. 2013) and $\Delta$, (Caumon et al., 2016)) and $423 \mathrm{~K}(\bullet,($ Hou et al. 2013)). Solid lines: GC-PR-CPA EoS. Dotted lines: E-PPR78 EoS. Dashed lines: geochemical model 
Figure 5: $\mathrm{CO}_{2}$ aqueous mole fraction versus pressure for the $\mathrm{CO}_{2}-\mathrm{CH}_{4}-\mathrm{H}_{2} \mathrm{O}$ system at $375 \mathrm{~K}$. Experimental data (Qin et al., 2008): (•) pure $\mathrm{CO}_{2},(\boldsymbol{\Delta}) 72 \% \mathrm{CO}_{2},(\bullet) 53 \% \mathrm{CO}_{2}$ and (•) $41 \%$ $\mathrm{CO}_{2}$. Solid lines: GC-PR-CPA EoS. Dotted lines: E-PPR78. Dashed lines: geochemical model

Figure 6: $\mathrm{CH}_{4}$ aqueous mole fraction versus pressure for the $\mathrm{CO}_{2}-\mathrm{CH}_{4}-\mathrm{H}_{2} \mathrm{O}$ system at $375 \mathrm{~K}$. Experimental data (Qin et al., 2008): (•) pure $\mathrm{CH}_{4},(\boldsymbol{\Delta}) 72 \% \mathrm{CO}_{2},(\bullet) 53 \% \mathrm{CO}_{2}$ and (๘) $41 \%$ $\mathrm{CO}_{2}$. Solid lines: GC-PR-CPA EoS. Dotted lines: E-PPR78. Dashed lines: geochemical model

Figure 7: Water content versus pressure for the $50 \% \mathrm{CO}_{2}-50 \% \mathrm{CH}_{4}-\mathrm{H} 2 \mathrm{O}$ system at $373 \mathrm{~K}$. Experimental data: $(\diamond)$ (Qin et al., 2008) and $(\diamond)$ (Al Ghafri et al., 2014).Solid lines: GC-PRCPA EoS. Dotted lines: E-PPR78. Dashed lines: geochemical model. Broken dotted line: PRCPA EoS with $\mathrm{k}_{\mathrm{ij}}=0$.

Figure 8: Water content versus pressure for the $50 \% \mathrm{CO}_{2}-50 \% \mathrm{CH}_{4}-\mathrm{H}_{2} \mathrm{O}$ system (Chapoy et al., 2016)at $293(\bullet)$ and $313 \mathrm{~K}(\boldsymbol{\Delta})$.Solid lines: GC-PR-CPA EoS. Dotted lines: E-PPR78. Dashed lines: geochemical model. Broken dotted line: PR-CPA EoS with $\mathrm{k}_{\mathrm{ij}}=0$.

Figure 9: $\mathrm{CO}_{2}$ aqueous mole fraction versus pressure for the $\mathrm{CO}_{2}-\mathrm{N}_{2}-\mathrm{H}_{2} \mathrm{O}$ system at $318 \mathrm{~K}$. Experimental data (Liu et al., 2012): (४) pure $\mathrm{CO}_{2},(\boldsymbol{\Delta}) 89 \% \mathrm{CO}_{2},(\bullet) 72 \% \mathrm{CO}_{2}$ and (๘) $57 \%$ $\mathrm{CO}_{2}$. Solid lines: GC-PR-CPA EoS. Dotted lines: E-PPR78. Dashed lines: geochemical model

Figure 10: $\mathrm{N}_{2}$ aqueous mole fraction versus pressure for the $\mathrm{CO}_{2}-\mathrm{N}_{2}-\mathrm{H}_{2} \mathrm{O}$ system at $318 \mathrm{~K}$. Experimental data (Liu et al., 2012): (४) pure $\mathrm{N}_{2},(\boldsymbol{\Delta}) 89 \% \mathrm{CO}_{2},(\bullet) 72 \% \mathrm{CO}_{2}$ and (घ) 57\% $\mathrm{CO}_{2}$. Solid lines: GC-PR-CPA EoS. Dotted lines: E-PPR78. Dashed lines: geochemical model

Figure 11: $\mathrm{CO}_{2}(\bullet), \mathrm{CH}_{4}(\boldsymbol{\Delta})$ and $\mathrm{H}_{2} \mathrm{~S}(\bullet)$ aqueous mole fraction versus pressure for the $30 \%$ $\mathrm{CO}_{2}-15 \% \mathrm{CH}_{4}-5 \% \mathrm{H}_{2} \mathrm{~S}-50 \% \mathrm{H}_{2} \mathrm{O}$ system at $380 \mathrm{~K}$ (Robinson et al., 1982). Solid lines: GCPR-CPA EoS. Dotted lines: E-PPR78. Dashed lines: geochemical model

Figure 12: Water content ( $)$ versus pressure for the $30 \% \mathrm{CO}_{2}-15 \% \mathrm{CH}_{4}-5 \% \mathrm{H}_{2} \mathrm{~S}-50 \% \mathrm{H}_{2} \mathrm{O}$ system at $380 \mathrm{~K}$ (Robinson et al., 1982). Solid lines: GC-PR-CPA EoS. Dotted lines: EPPR78. Dashed line: geochemical model

\section{APPENDIX}

\section{- Pure compounds}

With the presence of water or associating molecules, an associating term (from Wertheim's theory and perturbation theory) is added to the PR EoS. Two functions must be defined: the radial distribution function $g(d)$ of the reference fluid (hard sphere) (eq. A.2) and the fraction of non-bonded associating molecules $X^{A}$ (eq. A.3):

$$
g(d)^{\operatorname{sim} p}=\frac{1}{1-1.9 \eta}
$$

With

$$
\eta=\frac{1}{4} b \rho=\frac{b}{4 v}
$$




$$
X^{A_{i}}=\frac{1}{1+\rho \sum_{j} n_{j} \sum_{B_{i}} X^{B_{i}} \Delta^{A_{i} B_{i}}}
$$

with

$$
\Delta^{A_{i} B_{i}}=g(d)^{\operatorname{simp}}\left[\exp \left(\frac{\varepsilon^{A_{i} B_{i}}}{R T}\right)-1\right] \beta^{A_{i} B_{i} b}
$$

\section{- Mixtures}

Classical mixing rules are used in both E-PPR78 and GC-PR-CPA EoSs. They are given by equations A.4 and A.5

$$
\begin{gathered}
a_{i j}(T)=\sum_{i=1}^{N} \sum_{j=1}^{N} x_{i} x_{j} \sqrt{a_{i}(T) a_{j}(T)}\left(1-k_{i j}\right) \\
b_{i j}=\sum_{i=1}^{N} z_{i} b_{i}
\end{gathered}
$$

The binary interaction parameter $k_{i j}$ is defined as follow for the E-PPR78 EoS (eq. A.6 and A.7)

$$
k_{i j}(T)=\frac{-\frac{1}{2} \times \operatorname{Sum}-\left(\frac{\sqrt{\alpha_{i}(T)}}{b_{i}}-\frac{\sqrt{\alpha_{j}(T)}}{b_{j}}\right)^{2}}{2 \frac{\sqrt{\alpha_{i}(T) \alpha_{j}(T)}}{b_{i} b_{j}}}
$$

with

$$
S u m=\sum_{k=1}^{N g} \sum_{l=1}^{N g}\left(\alpha_{i k}-\alpha_{j k}\right)\left(\alpha_{i l}-\alpha_{j l}\right) A_{k l}\left(\frac{298.15}{T}\right)^{\left(\frac{B_{k l}}{A_{k l}}-1\right)}
$$


This binary interaction parameter has been modified when considering water in the GC-PRCPA EoS. Equation A.7 becomes equation A.8:

$$
\begin{aligned}
& \text { Sum }_{\text {asso }}=\sum_{k=1}^{\mathrm{H}_{2} \mathrm{O}}\left(\alpha_{i k}-\alpha_{j k}\right)\left(\alpha_{i_{2} \mathrm{O}}-\alpha_{\mathrm{j}_{2} \mathrm{O}}\right)\left(C_{k \mathrm{H}_{2} \mathrm{O}} T^{2}+D_{k \mathrm{H}_{2} \mathrm{O}} T+E_{k \mathrm{H}_{2} \mathrm{O}}\right) \\
& +\sum_{l=1}^{\mathrm{H}_{2} \mathrm{O}}\left(\alpha_{i_{2} \mathrm{O}}-\alpha_{j \mathrm{H}_{2} \mathrm{O}}\right)\left(\alpha_{i l}-\alpha_{j l}\right)\left(C_{\mathrm{H}_{2} \mathrm{Ol}} T^{2}+D_{\mathrm{H}_{2} \mathrm{Ol}} T+E_{\mathrm{H}_{2} \mathrm{Ol}}\right)
\end{aligned}
$$

Finally, combining rules have to be used in the associating term of the GC-PR-CPA EoS. The Combining Rule CR1 (Hajiw et al., 2015) is used in our GC-PR-CPA EoS (eq. A.9 and A.10).

$$
\begin{aligned}
& \varepsilon^{A_{i} B_{j}}=\frac{\varepsilon^{A_{i} B_{i}}+\varepsilon^{A_{j} B_{j}}}{2} \\
& \beta^{A_{i} B_{j}}=\sqrt{\beta^{A_{i} B_{i}} \beta^{A_{j} B_{j}}}
\end{aligned}
$$

\section{REFERENCES}

Agency, P.N.E.A., 2014, Trends in Global CO2 Emissions 2014 Report.

Al Ghafri, S.Z.S., Forte, E., Maitland, G.C., Rodriguez-Henriquez, J.J. and Trusler, J.P.M., 2014, Experimental and Modeling Study of the Phase Behavior of (Methane + CO2 + Water) Mixtures. Journal of Physical Chemistry B, 118(49), 14461-14478.

Caumon, M.-C., Sterpenich, J., Randi, A. and Pironon, J., 2016, Measuring mutual solubility in the H2O-CO2 system up to 200 bar and 100 degrees $C$ by in situ Raman spectroscopy. International Journal of Greenhouse Gas Control, 47, 63-70.

Chapoy, A., Burgass, R., Terrigeol, A., Coquelet, C., 2016, Water Content of CO2 rich Mixtures: Measurements and Modeling using the Cubic-Plus-Association Equation of State. Journal of Natural Gas Engineering, 1(13), 85-97.

Corvisier, J., 2013, Modeling Gas-Rock Interactions using CHESS/HYTEC, in Goldschmidt Conference. Florence - Italy.

Corvisier, J., Bonvalot A.-F., Lagneau, V., Chiquet, P., Renard, S., Sterpenich, J. and Pironon, J., 2013, Impact of co-injected gases on $\mathrm{CO} 2$ storage sites: geochemical modeling of experimental results. Energy Procedia GGHT-11, 37, 3699-3710.

Dhima, A., de Hemptinne, J.C. and Jose, J.,1999, Solubility of hydrocarbons and CO2 mixtures in water under high pressure. Industrial \& Engineering Chemistry Research, 38(8), 3144-3161.

Duan, Z., Sun, R., Liu, R. and Zhu, C., 2007, Accurate thermodynamic model for the calculation of H2S solubility in pure water and brines. Energy \& Fuels, 21(4), 2056-2065.

Duan, Z.H. and Sun, R., 2003, An improved model calculating CO2 solubility in pure water and aqueous $\mathrm{NaCl}$ solutions from 273 to $533 \mathrm{~K}$ and from 0 to 2000 bar. Chemical Geology, 193(3-4), 257-271. 
Duan, Z. and Mao, 2006, S., A thermodynamic model for calculating methane solubility, density and gas phase composition of methane-bearing aqueous fluids from 273 to $523 \mathrm{~K}$ and from 1 to 2000 bar. Geochimica Et Cosmochimica Acta, 70(13), 3369-3386.

European Communities, 2011, Implementation of Directive 2009/31/EC on the Geological Storage of Carbon Dioxide, Guidance Document 2. Characterisation of the Storage Complex, CO2 Stream Composition, Monitoring and Corrective Measures, 1-155.

Fredenslund, A., Jones, R.L. and Prausnitz, J.M., 1975, Group-contribution estimation of activity coefficients in nonideal liquid mixtures. AIChE Journal, 21(6), 1086-1099.

Geng, M. and Duan, Z.H., 2010, Prediction of oxygen solubility in pure water and brines up to high temperatures and pressures. Geochimica Et Cosmochimica Acta, 74(19), 5631-5640.

Hajiw, M., 2014, Hydrate Mitigation in Sour and Acid Gases, Mines ParisTech \& Heriot Watt University.

Hajiw, M., Chapoy, A. and Coquelet, C., 2015, Hydrocarbons - water phase equilibria using the CPA equation of state with a group contribution method. Canadian Journal of Chemical Engineering, 93(2), 432-442.

Hou, S.-X., Maitland, G.C. and Trusler, J.P.M., 2013, Measurement and modeling of the phase behavior of the (carbon dioxide plus water) mixture at temperatures from $298.15 \mathrm{~K}$ to $448.15 \mathrm{~K}$. Journal of Supercritical Fluids, 73, 87-96.

Jaubert, J.-N. and Mutelet, F., 2004, VLE predictions with the Peng-Robinson equation of state and temperature dependent k(ij) calculated through a group contribution method. Fluid Phase Equilibria, 224(2), 285-304.

Liebscher, A., Möller, F., Bannch, A., Köhler, S., Wiebach, J., Schmidt-Hattenberger, C., Weiner, M., Pretschner, C., Ebert, K. and Zemke, J., 2013, Injection operation and operational pressure-temperature monitoring at the $\mathrm{CO} 2$ storage pilot site Ketzin, Germany-Design, results, recommendations. International Journal of Greenhouse Gas Control, 15, 163-173.

Liu, Y., Hou, M., Ning, H., Yang, D., Yang, G. and Han, B., 2012, Phase Equilibria of CO2 + N2 + H2O and N2 $+\mathrm{CO} 2+\mathrm{H} 2 \mathrm{O}+\mathrm{NaCl}+\mathrm{KCl}+\mathrm{CaCl} 2$ Systems at Different Temperatures and Pressures. Journal of Chemical and Engineering Data, 57(7), 1928-1932.

Mao, S. and Duan, Z., 2006, A thermodynamic model for calculating nitrogen solubility, gas phase composition and density of the N2-H2O-NaCl system. Fluid Phase Equilibria, 248(2), 103-114.

Meunier, N., Laribi, S., Dubois, L., Thomas, D. and De Weireld, G., 2014, CO2 capture in cement production and re-use: first step for the optimization of the overall process. Energy Procedia, GHGT-12, 63, 6492-6503.

Peng, D. and Robinson, D.B., 1976, New two-constant equation of state. Industrial \& Engineering Chemistry Fundamentals, 15(1), 59-64.

Qian, J.-W., Privat, R., Jaubert, J.-N. and Duchet-Suchaux, P., 2013, Enthalpy and Heat Capacity Changes on Mixing: Fundamental Aspects and Prediction by Means of the PPR78 Cubic Equation of State. Energy \& Fuels, 27(11), 7150-7178.

Qin, J., R.J. Rosenbauer, and Z. Duan, 2008, Experimental measurements of vapor-liquid equilibria of the $\mathrm{H}_{2} \mathrm{O}+\mathrm{CO}_{2}+\mathrm{CH}_{4}$ ternary system. Journal of Chemical and Engineering Data, 53(6), 1246-1249.

Robinson, D.B., Huang, S.S., Leu, A.D. and Ng, H.J., 1982, The Phase Behavior of Two Mixtures of Methane, Carbon Dioxide, Hydrogen Sulfide, and Water, Gas Processors Association RR-57.

Rumpf, B. and Maurer, G., 1992, Solubilities of hydrogen-cyanide and sulfur dioxide in water at temperatures from 293.15 to $413.15 \mathrm{~K}$ and pressures up to $2.5 \mathrm{MPa}$. Fluid Phase Equilibria, 81(1-2), 241-260.

Song, K.Y. and Kobayashi, R., 1990, The water content of a CO2-rich gas-mixture containing 5.31 mol percent methane along the 3-phase and supercritical conditions. Journal of Chemical and Engineering Data, 35(3), 320322.

Tanger IV, J.C. and Helgeson, H.C., 1988, Calculation of the thermodynamic and transport properties of aqueous species at high pressures and temperatures: Revised equations of state for the standard partial molal properties of ions and electrolytes. American Journal of Science, 288(1), 19-98.

Wertheim M.S., 1984, fluids with highly directional attractive forces. I. Statistical thermodynamics, J. Stat. Phys., 35, 19-34.

$\mathrm{Xu}, \mathrm{X}$., Privat, R. and Jaubert, J.-N., 2015, Addition of the Sulfur Dioxide Group (SO2), the Oxygen Group (O2), and the Nitric Oxide Group (NO) to the E-PPR78 Model. Industrial \& Engineering Chemistry Research, 54(38), 9494-9504.

Zirrahi, M., Azin, R., Hasaandazeh, H. and Moshfeghian, M., 2012, Mutual solubility of CH4, CO2, H2S and their mixtures in brine under subsurface disposal conditions. Fluid Phase Equilibria, 324, 80-93. 


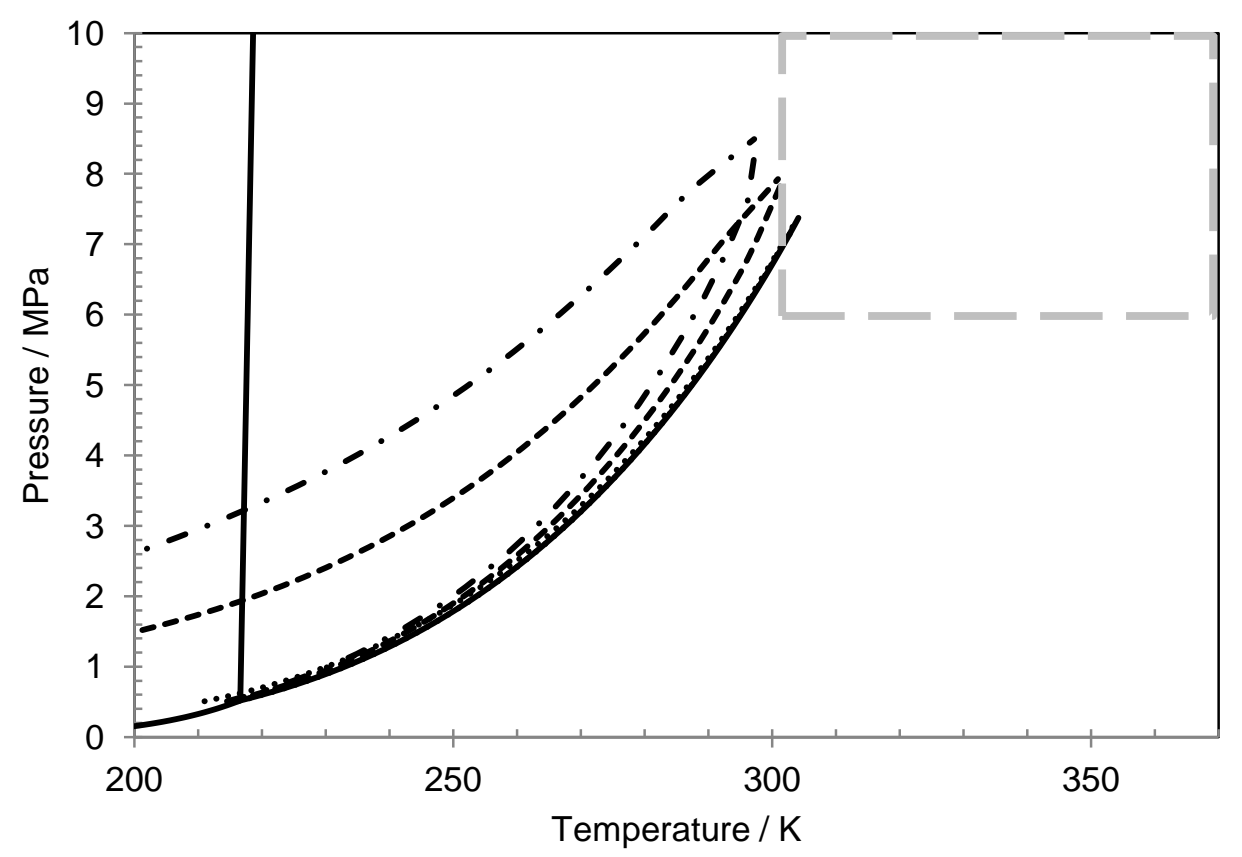

Figure 3: Pressure-Temperature diagram. Solid line: pure $\mathrm{CO}_{2}$. Broken dotted line: Case A. Dashed line: Case B. Dotted line: Case C. Grey square: storage conditions in saline aquifers. 


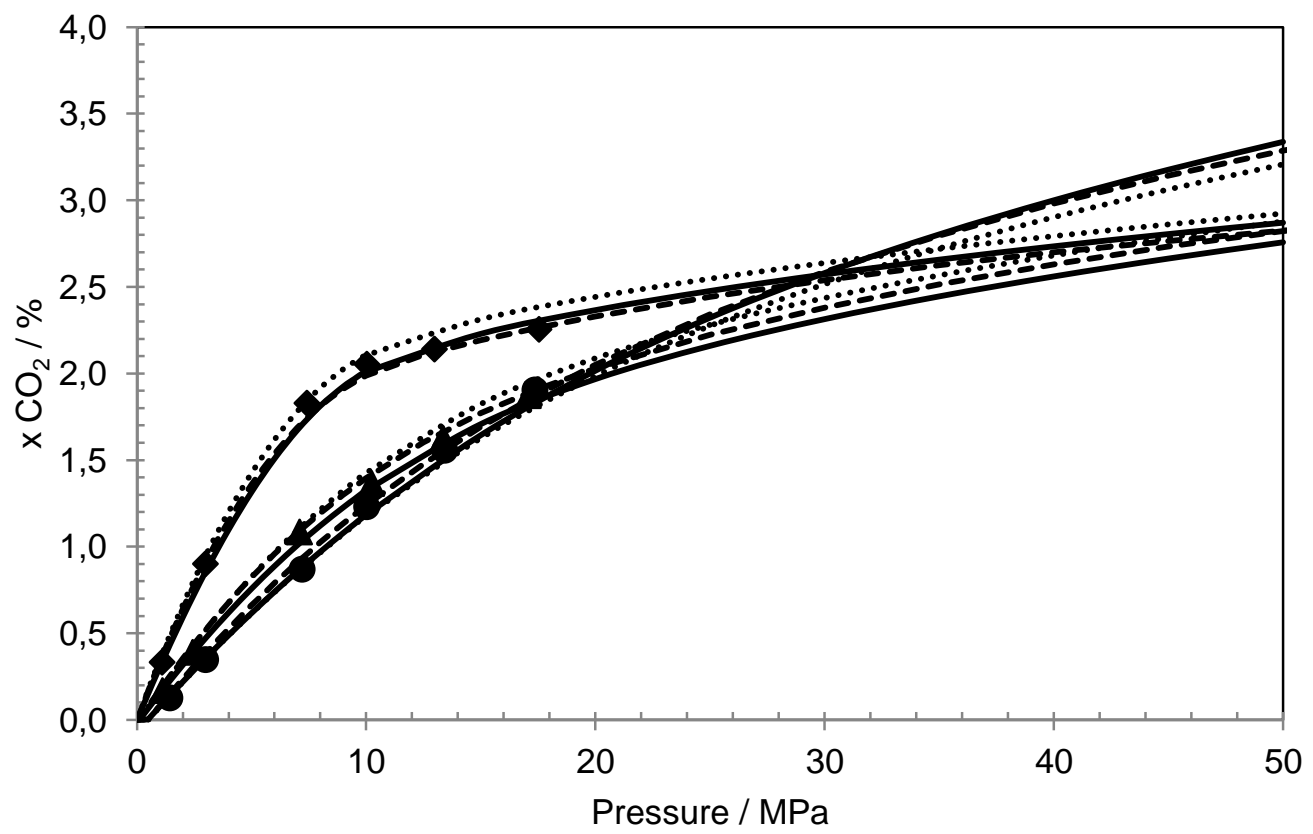

Figure 4: $\mathrm{CO}_{2}$ solubility in water at $323 \mathrm{~K}(\bullet), 373 \mathrm{~K}(\boldsymbol{\Delta})$ and $423 \mathrm{~K}(\bullet)$ (Hou et al. 2013). Solid lines: GC-PR-CPA EoS. Dotted lines: E-PPR78 EoS. Dashed lines: geochemical model 


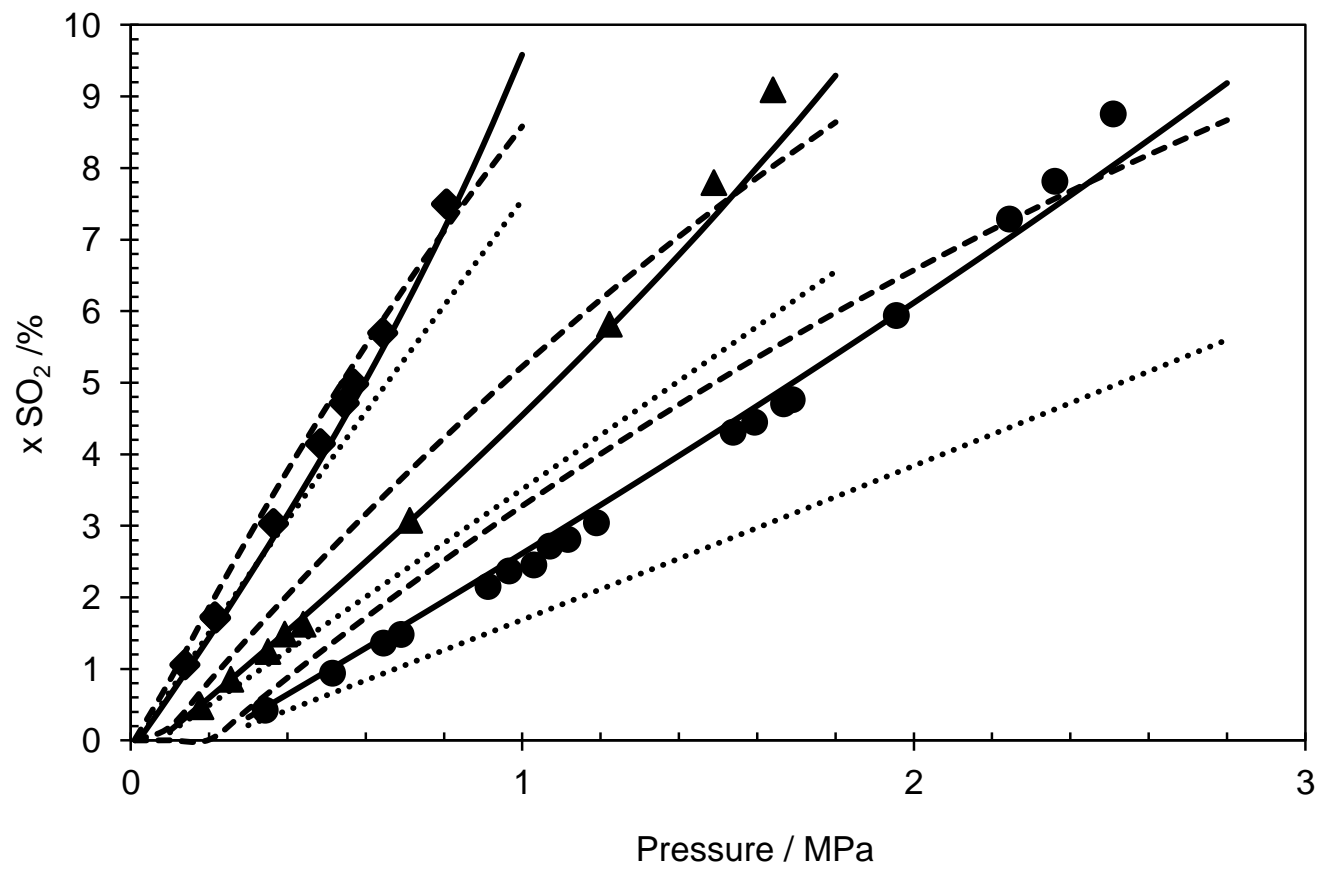

Figure 3: $\mathrm{SO}_{2}$ solubility in water at $333 \mathrm{~K}(\bullet), 363 \mathrm{~K}(\boldsymbol{\Delta})$ and $393 \mathrm{~K}(\bullet)$ (Rumpf and Maurer, 1992). Solid lines: GC-PR-CPA EoS. Dotted lines: E-PPR78 EoS. Dashed lines: geochemical model 


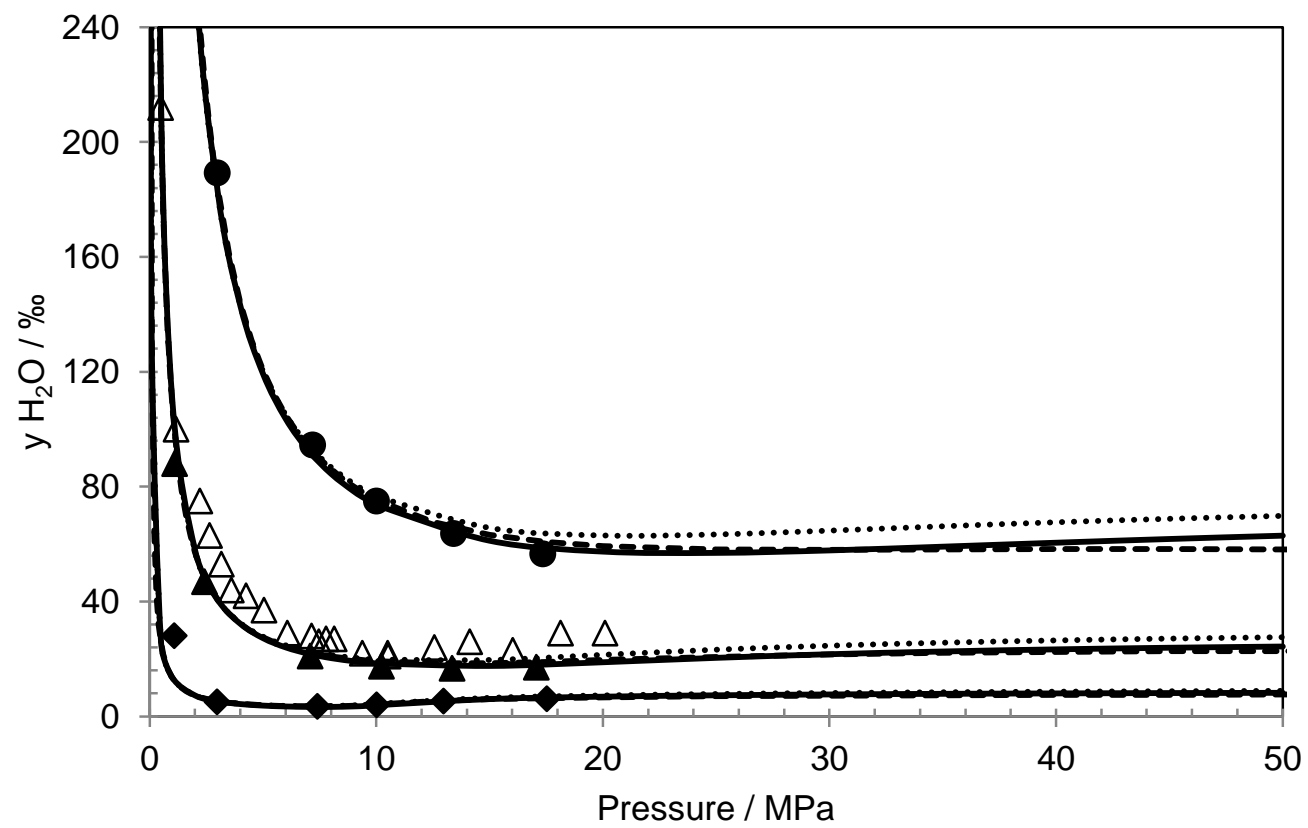

Figure 4: Water content at $323 \mathrm{~K}(\diamond$, (Hou et al. 2013)), $373 \mathrm{~K}(\boldsymbol{\Delta}$, (Hou et al. 2013) and $\Delta$, (Caumon et al., 2016)) and $423 \mathrm{~K}(\bullet,($ Hou et al. 2013)). Solid lines: GC-PR-CPA EoS. Dotted lines: E-PPR78 EoS. Dashed lines: geochemical model 


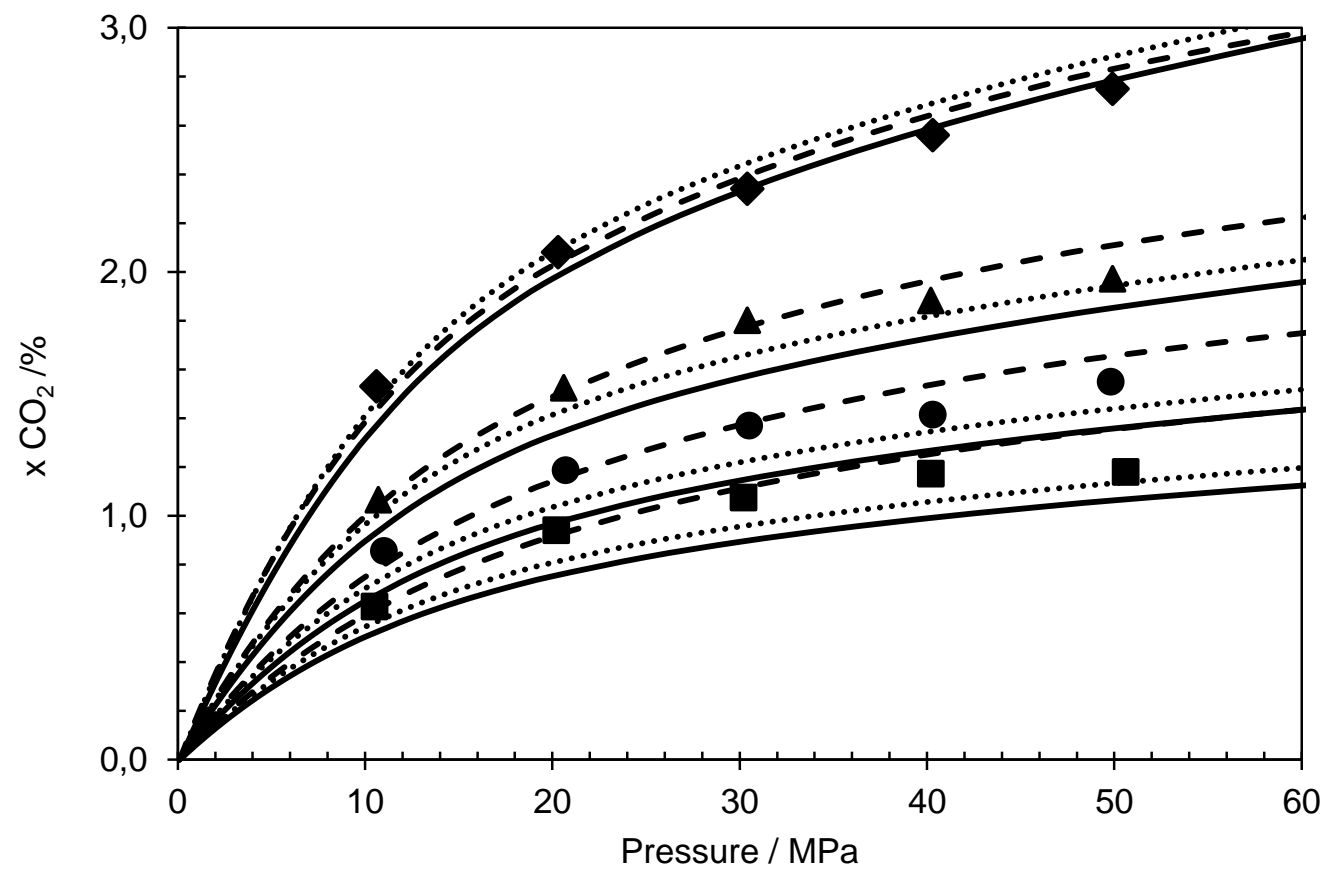

Figure 5: $\mathrm{CO}_{2}$ aqueous mole fraction versus pressure for the $\mathrm{CO}_{2}-\mathrm{CH}_{4}-\mathrm{H}_{2} \mathrm{O}$ system at $375 \mathrm{~K}$. Experimental data (Qin et al., 2008): (४) pure $\mathrm{CO}_{2},(\boldsymbol{\Delta}) 72 \% \mathrm{CO}_{2},(\bullet) 53 \% \mathrm{CO}_{2}$ and (•) 41\% $\mathrm{CO}_{2}$. Solid lines: GC-PR-CPA EoS. Dotted lines: E-PPR78. Dashed lines: geochemical model 


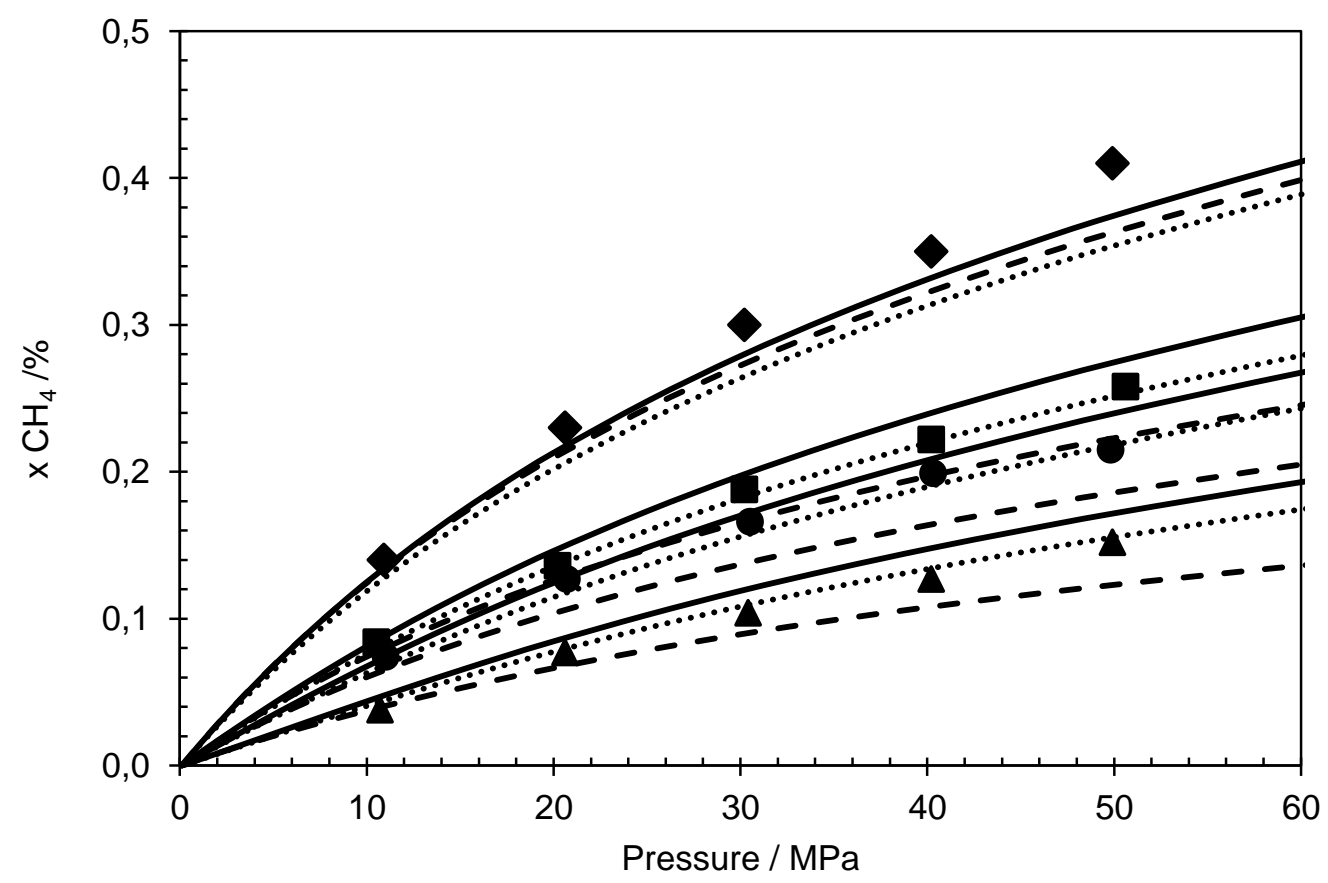

Figure 6: $\mathrm{CH}_{4}$ aqueous mole fraction versus pressure for the $\mathrm{CO}_{2}-\mathrm{CH}_{4}-\mathrm{H}_{2} \mathrm{O}$ system at $375 \mathrm{~K}$. Experimental data (Qin et al., 2008): ( $)$ pure $\mathrm{CH}_{4},(\boldsymbol{\Delta}) 72 \% \mathrm{CO}_{2},(\bullet) 53 \% \mathrm{CO}_{2}$ and (๘) 41\% $\mathrm{CO}_{2}$. Solid lines: GC-PR-CPA EoS. Dotted lines: E-PPR78. Dashed lines: geochemical model 


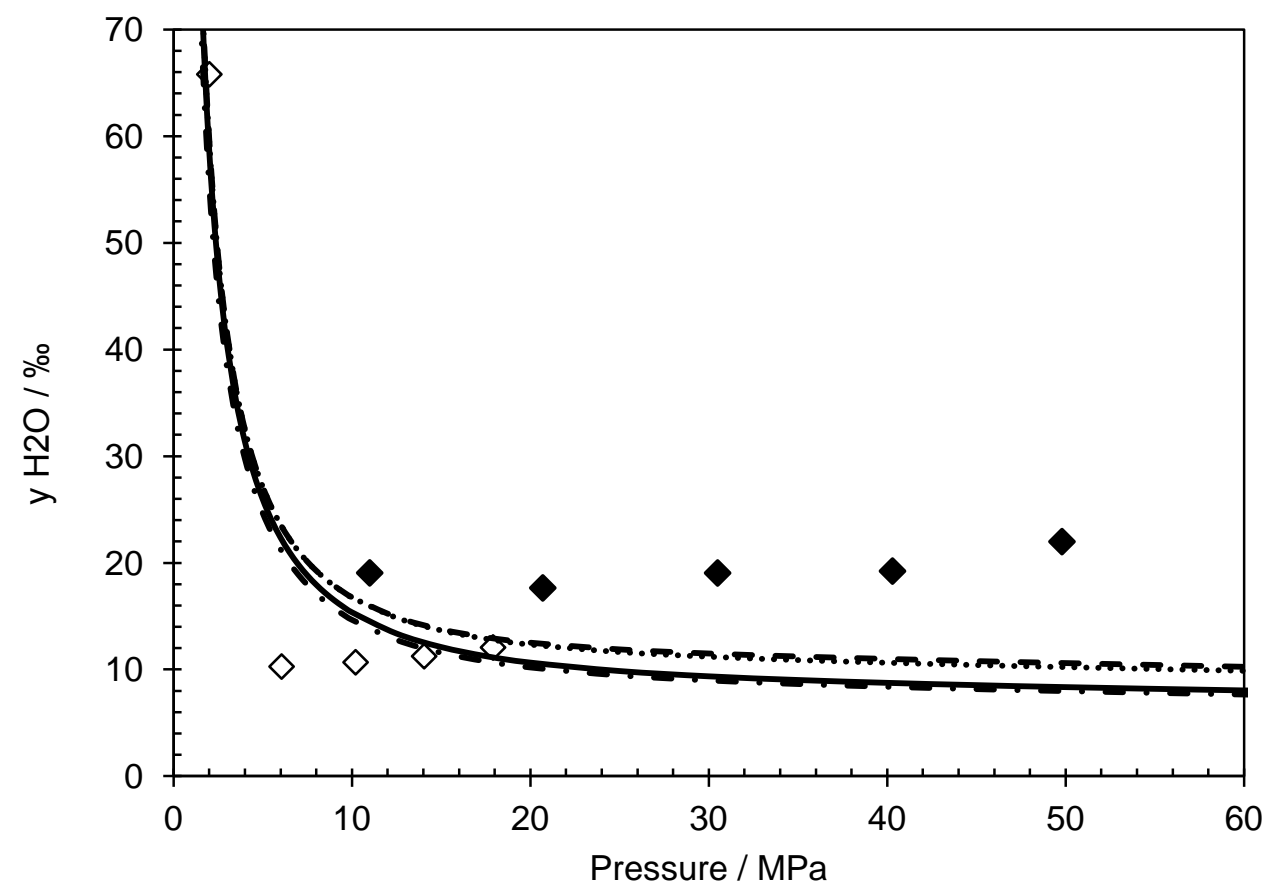

Figure 7: Water content versus pressure for the $50 \% \mathrm{CO}_{2}-50 \% \mathrm{CH}_{4}-\mathrm{H} 2 \mathrm{O}$ system at $373 \mathrm{~K}$. Experimental data: $(\diamond)$ (Qin et al., 2008) and $(\diamond)$ (Al Ghafri et al., 2014).Solid lines: GC-PRCPA EoS. Dotted lines: E-PPR78. Dashed lines: geochemical model. Broken dotted line: PRCPA EoS with $\mathrm{k}_{\mathrm{ij}}=0$. 


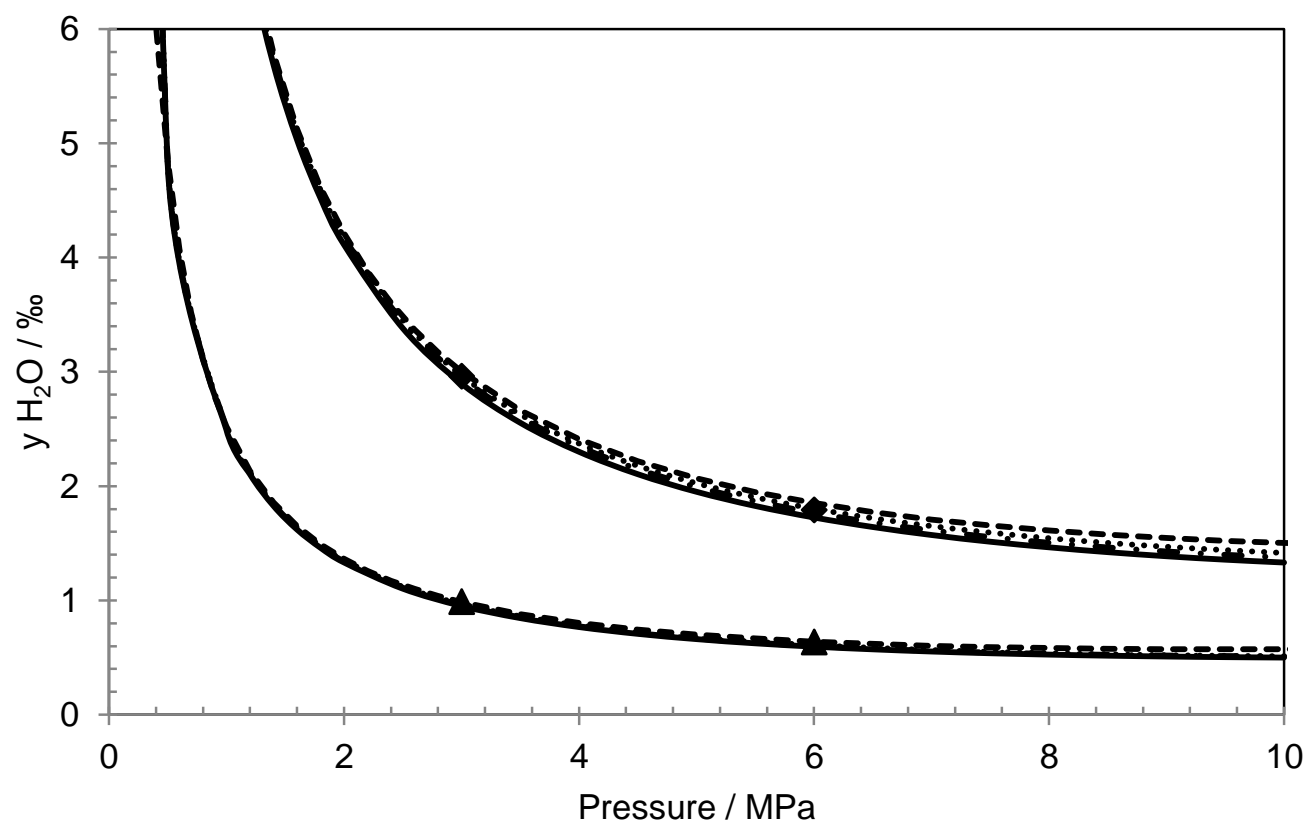

Figure 8: Water content versus pressure for the $50 \% \mathrm{CO}_{2}-50 \% \mathrm{CH}_{4}-\mathrm{H}_{2} \mathrm{O}$ system (Chapoy et al., 2016)at $293(\diamond)$ and 313 K ( $\Delta$ ).Solid lines: GC-PR-CPA EoS. Dotted lines: E-PPR78.

Dashed lines: geochemical model. Broken dotted line: PR-CPA EoS with $\mathrm{k}_{\mathrm{ij}}=0$. 


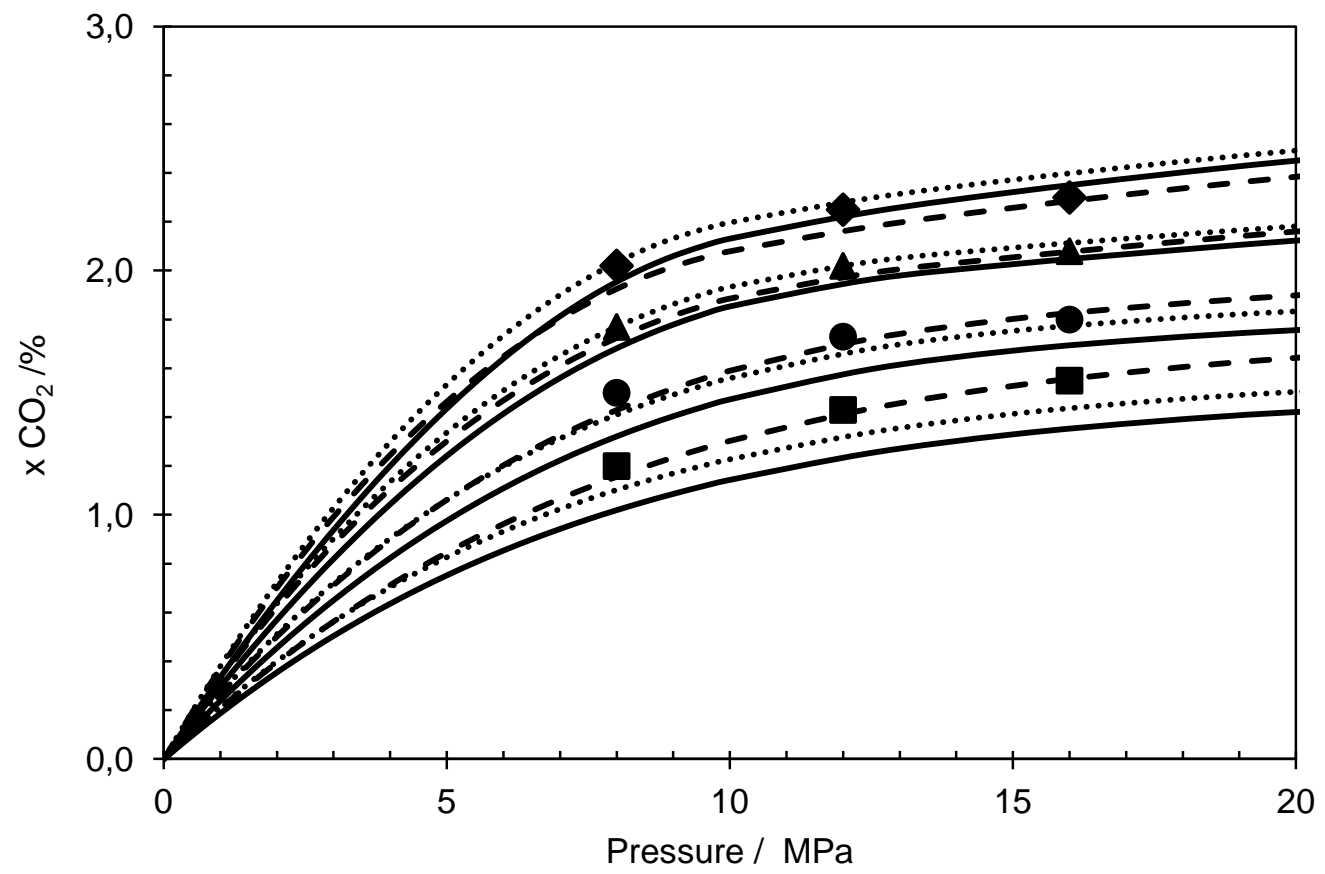

Figure 9: $\mathrm{CO}_{2}$ aqueous mole fraction versus pressure for the $\mathrm{CO}_{2}-\mathrm{N}_{2}-\mathrm{H}_{2} \mathrm{O}$ system at $318 \mathrm{~K}$. Experimental data (Liu et al., 2012): (•) pure $\mathrm{CO}_{2},(\boldsymbol{\Delta}) 89 \% \mathrm{CO}_{2},(\bullet) 72 \% \mathrm{CO}_{2}$ and (๘) 57\% $\mathrm{CO}_{2}$. Solid lines: GC-PR-CPA EoS. Dotted lines: E-PPR78. Dashed lines: geochemical model 


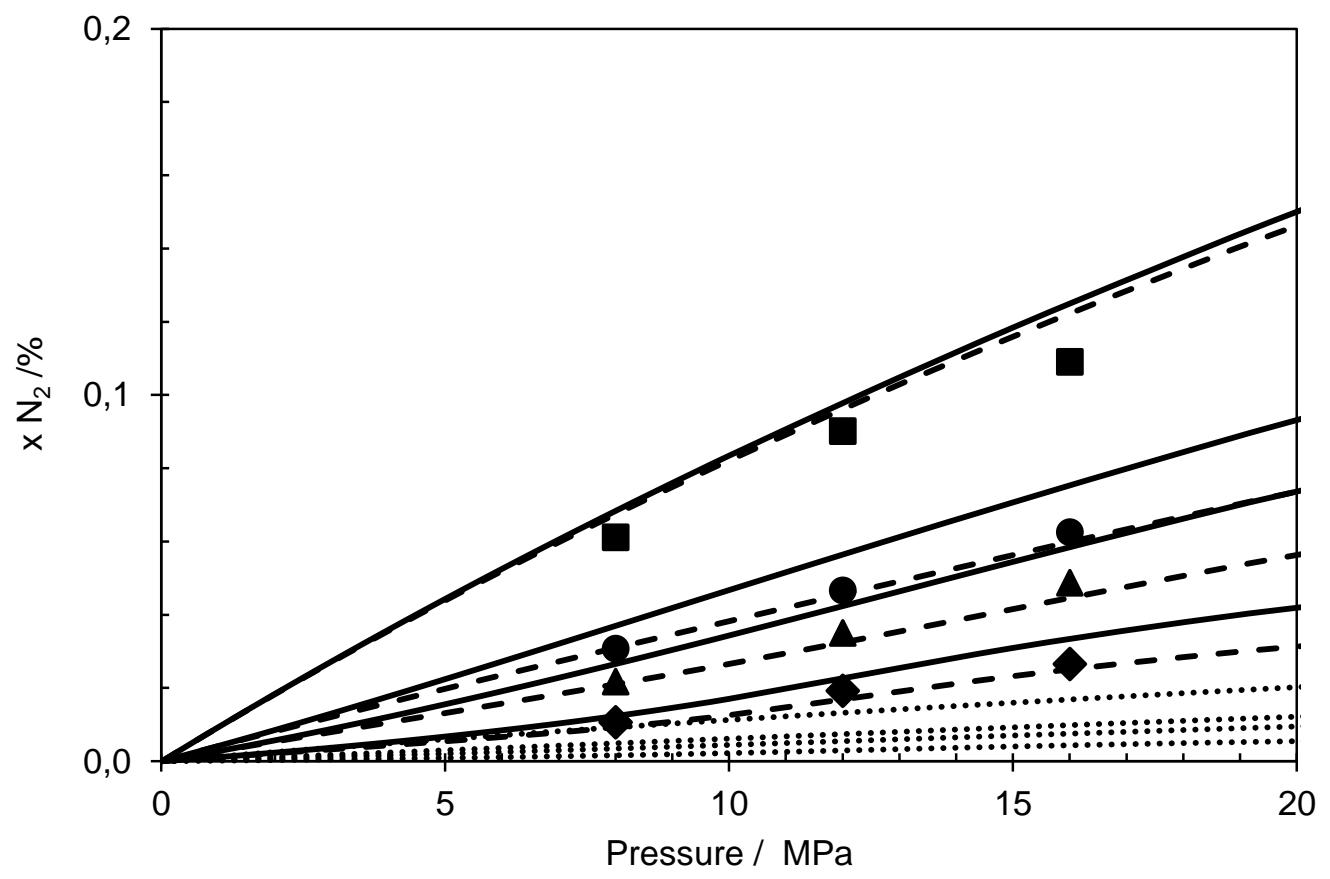

Figure 10: $\mathrm{N}_{2}$ aqueous mole fraction versus pressure for the $\mathrm{CO}_{2}-\mathrm{N}_{2}-\mathrm{H}_{2} \mathrm{O}$ system at $318 \mathrm{~K}$. Experimental data (Liu et al., 2012): (४) pure $\mathrm{N}_{2},(\boldsymbol{\Delta}) 89 \% \mathrm{CO}_{2},(\bullet) 72 \% \mathrm{CO}_{2}$ and (घ) $57 \%$ $\mathrm{CO}_{2}$. Solid lines: GC-PR-CPA EoS. Dotted lines: E-PPR78. Dashed lines: geochemical model 


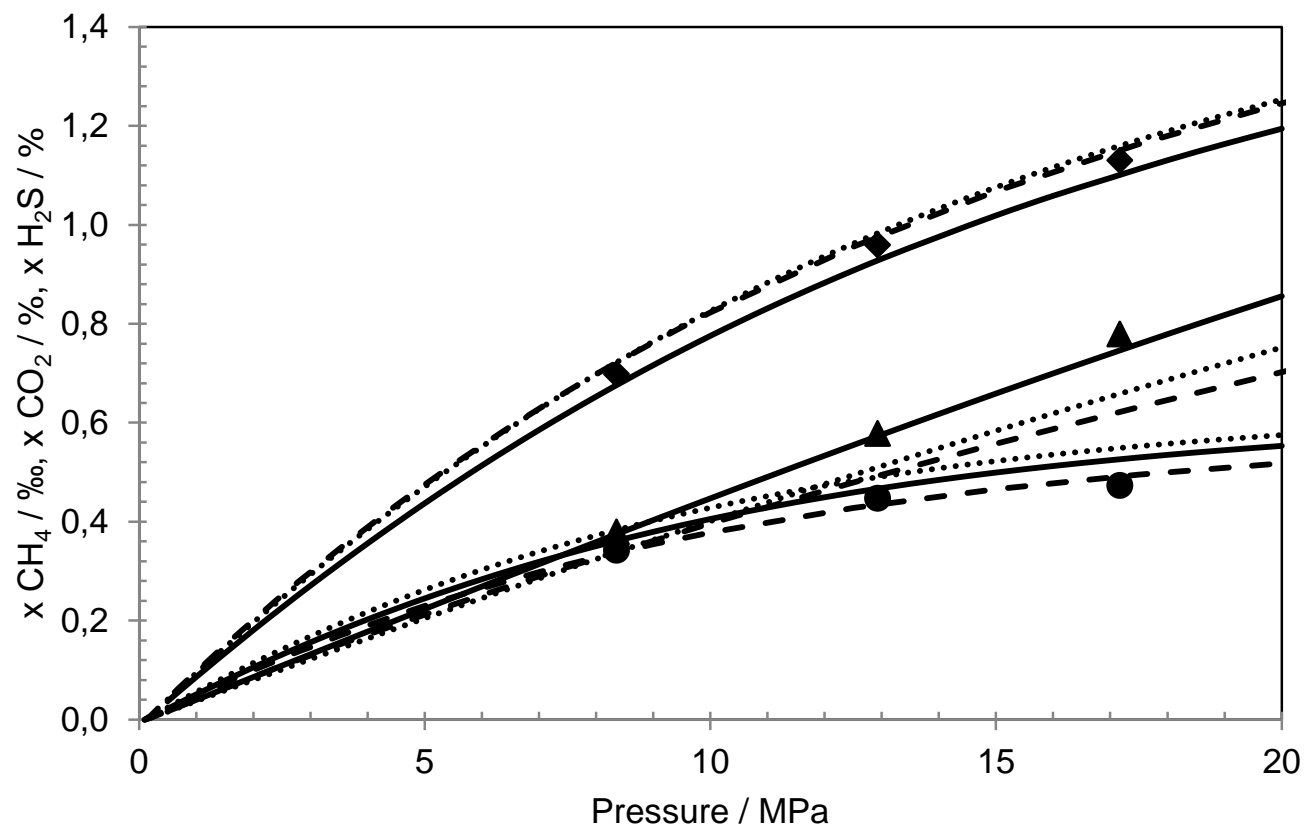

Figure 11: $\mathrm{CO}_{2}(\diamond), \mathrm{CH}_{4}(\boldsymbol{\Delta})$ and $\mathrm{H}_{2} \mathrm{~S}(\bullet)$ aqueous mole fraction versus pressure for the $30 \%$ $\mathrm{CO}_{2}-15 \% \mathrm{CH}_{4}-5 \% \mathrm{H}_{2} \mathrm{~S}-50 \% \mathrm{H}_{2} \mathrm{O}$ system at $380 \mathrm{~K}$ (Robinson et al., 1982). Solid lines: GCPR-CPA EoS. Dotted lines: E-PPR78. Dashed lines: geochemical model 


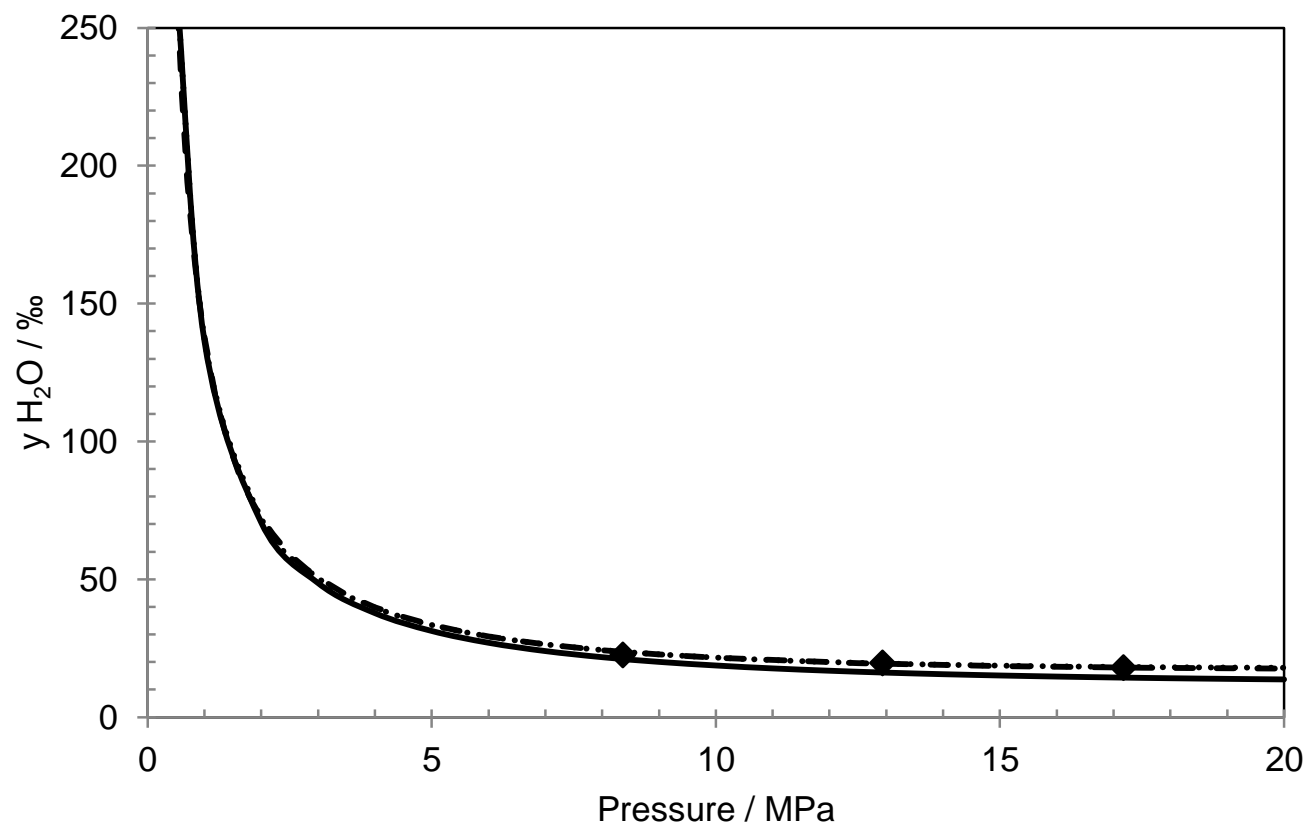

Figure 12: Water content ( $)$ versus pressure for the $30 \% \mathrm{CO}_{2}-15 \% \mathrm{CH}_{4}-5 \% \mathrm{H}_{2} \mathrm{~S}-50 \% \mathrm{H}_{2} \mathrm{O}$ system at $380 \mathrm{~K}$ (Robinson et al., 1982). Solid lines: GC-PR-CPA EoS. Dotted lines: EPPR78. Dashed line: geochemical model 
Table 10: Example of compositions of flue gases from thermal power plant (Case A, (Meunier et al., 2014)), a cement plant (Case B, (Meunier et al., 2014)) and a coal IGCC plant (Case C, European Communities, 2011)).

\begin{tabular}{cccc}
\hline \multirow{2}{*}{ Component } & \multicolumn{3}{c}{ Composition in mole \% } \\
\cline { 2 - 4 } & Case A & Case B & Case C \\
\hline $\mathrm{CO}_{2}$ & 72 & 83.13 & 98.1 \\
\hline $\mathrm{H}_{2} \mathrm{O}$ & 5.6 & 1 & $376 \mathrm{ppm}$ \\
\hline $\mathrm{N}_{2}$ & 14 & 11.11 & $196 \mathrm{ppm}$ \\
\hline $\mathrm{O}_{2}$ & 5.9 & 3.27 & - \\
\hline $\mathrm{Ar}$ & 2.4 & 1.34 & 0.13 \\
\hline $\mathrm{CO}$ & - & $397 \mathrm{ppm}$ & - \\
\hline $\mathrm{NO}$ & $320 \mathrm{ppm}$ & $861 \mathrm{ppm}$ & - \\
\hline $\mathrm{NO}_{2}$ & $51 \mathrm{ppm}$ & $96 \mathrm{ppm}$ & 0.17 \\
\hline $\mathrm{SO}_{2}$ & $700 \mathrm{ppm}$ & $156 \mathrm{ppm}$ & $112 \mathrm{ppm}$ \\
\hline $\mathrm{H}_{2} \mathrm{~S}$ & - & - & 1.5 \\
\hline $\mathrm{CH}_{4}$ & - & - & \\
\hline $\mathrm{H}_{2}$ & - & - & \\
\hline
\end{tabular}


Table 11: Gas solubility data in pure water.

\begin{tabular}{cccc}
\hline Component & References & $\begin{array}{c}\text { Range of } \\
\text { temperatures [K] }\end{array}$ & $\begin{array}{c}\text { Range of } \\
\text { pressures [MPa] }\end{array}$ \\
\hline $\mathbf{C O}_{\mathbf{2}}$ & {$[1-6]$} & $273-623$ & $0.008-150$ \\
\hline $\mathbf{N}_{\mathbf{2}}$ & {$[7-11]$} & $273-636.5$ & $0.02-101$ \\
\hline $\mathbf{O}_{\mathbf{2}}$ & {$[11-32]$} & $273-616.5$ & $0.02-20$ \\
\hline $\mathbf{A r}$ & {$[11,17,27,33-40]$} & $273-568$ & $0.02-15$ \\
\hline $\mathbf{C O}$ & {$[41-48]$} & $273-478$ & $0.06-14$ \\
\hline $\mathbf{N O}$ & - & - & - \\
\hline $\mathbf{N O}$ & - & - & - \\
\hline $\mathbf{S O}$ & {$[49,50]$} & $293-393$ & $0.035-2$ \\
\hline $\mathbf{H}_{2} \mathbf{S}$ & {$[2,46,51-64]$} & $273-518$ & $0.01-31$ \\
\hline $\mathbf{C H}_{\mathbf{4}}$ & {$[42,65-74]$} & $273-523$ & $0.08-197$ \\
\hline $\mathbf{H}_{\mathbf{2}}$ & {$[15,43-45,66,75-86]$} & $273-498$ & $0.1-101$ \\
\hline
\end{tabular}

1. Takenouchi, S. and Kennedy, G.C., 1964, Binary system $\mathrm{H}_{2} \mathrm{O}-\mathrm{CO}_{2}$ at high temperatures + pressures. American Journal of Science, 262(9), 1055-1074.

2. Gillespie, P.C. and Wilson, G.M., 1982, Vapor liquid and liquid liquid equilibria: methane-water; water-carbon dioxide; water-hydrogen sulphide;water-n-pentane; water-methane-n-pentane, Gas Processors Association RR-48.

3. Hou, S.-X., Maitland, G.C. and Trusler, J.P.M., 2013, Measurement and modeling of the phase behavior of the (carbon dioxide plus water) mixture at temperatures from $298.15 \mathrm{~K}$ to $448.15 \mathrm{~K}$. Journal of Supercritical Fluids, 73, 87-96.

4. Wiebe, R. and Gaddy, V.L., 1939, The solubility in water of carbon dioxide at 50, 75 and 100 degrees, at pressures to 700 atmospheres. Journal of the American Chemical Society, 61,315-318.

5. Guo, H., Chen, Y., Hu, Q., Lu, W., Ou, W. and Geng, L., 2014, Quantitative Raman spectroscopic investigation of geo-fluids high-pressure phase equilibria: Part I. Accurate calibration and determination of $\mathrm{CO}_{2}$ solubility in water from 273.15 to $573.15 \mathrm{~K}$ and from 10 to $120 \mathrm{MPa}$. Fluid Phase Equilibria, 382, 70-79.

6. Yan, W., Huang, S. and Stenby, E.H., 2011, Measurement and modeling of $\mathrm{CO}_{2}$ solubility in $\mathrm{NaCl}$ brine and $\mathrm{CO}_{2}$-saturated $\mathrm{NaCl}$ brine density. International Journal of Greenhouse Gas Control, 5(6), $1460-1477$.

7. Wiebe, R., Gaddy, V.L. and Heins, C., 1933, The solubility of nitrogen in water at 50, 75 and 100(o) from 25 to 1000 atmospheres. Journal of the American Chemical Society, 55, 947-953.

8. Goodman, J.B. and Krase, N.W., 1931, Solubility of nitrogen in water at high pressures and temperatures. Industrial and Engineering Chemistry, 23, 401-404.

9. O’Sullivan. T.D, Smith, N.O. and Nagy, B., 1966, Solubility of natural gases in aqueous salts solutions - III Nitrogen in aqueous $\mathrm{NaCl}$ at high pressures. Geochimica Et Cosmochimica Acta, 30(6), 617-619.

10. Chapoy, A., Mohammadi, A.H., Tohidi, B. and Richon, D., 2004, Gas solubility measurement and modeling for the nitrogen plus water system from $274.18 \mathrm{~K}$ to $363.02 \mathrm{~K}$. Journal of Chemical and Engineering Data, 49(4), 1110-1115.

11. Douglas, E., 1964, Solubilities of oxygen, argon, and nitrogen in distilled water. Journal of Physical Chemistry, 68(1), 169-174. 
12. Adeney, W.E. and Becker, H.G., 1919, On the rate of solution of atmospheric nitrogen and oxygen by water. The Scientific proceedings of the Royal Dublin Society, 15, 609-628.

13. Livingston, J., Morgan, R. and Richardson, A.H., 1930, Solubility relations in gas-liquid systems IV The solubility of oxygen in water as found by an analytical method. Journal of Physical Chemistry, 34(10), 2356-2366.

14. Livingston, J., Morgan, R. and Pyne, H.R., 1930, Solubility relations in gas-liquid systems II The solubility and rate of solution of oxygen in water. Journal of Physical Chemistry, 34(8), 1818-1821.

15. Morrison, T.J. and Billett, F., 1952, The salting-out of non-electrolytes. Part II. The effect of variation in non-electrolyte. Journal of the Chemical Society, October, 3819-3822.

16. Pray, H.A., Schweickert, C.E. and Minnich, B.H., 1952, Solubility of hydrogen, oxygen, nitrogen, and helium in water at elevated temperatures. Industrial and Engineering Chemistry, 44(5), 1146-1151.

17. Klots, C.E. and Benson, B.B., 1963, Solubilities of nitrogen, oxygen, and argon in distilled water. Journal of Marine Research, 21(1), 48-57.

18. Montgomery, H.A.C., Thom, N.S. and Cockburn, 1964, A., Determination of dissolved oxygen by Winkler method and the solubility of oxygen in pure water and seawater. Journal of Applied Chemistry, 14(7), 280-296.

19. Carpenter J.H., 1966, New measurements of oxygen solubility in pure and natural water. Limnology and Oceanography, 11(2), 264-277.

20. Murray, C.N. and Riley, J.P., 1969, Solubility of gases in distilled water and seawater. II. Oxygen. Deep-Sea Research, 16(3), 311-320.

21. Novak, D.M. and Conway, B.E., 1973, Technique for repetitive gas solubility determinations at variuos pressures. Chemical Instrumentation, 5(2), 79-90.

22. Wilcock, R.J. and Battino, R., 1974, Solubility of oxygen-nitrogen mixture in water. Nature, 252(5484), 614-615.

23. Tokunaga, J., 1975, Solubilities of oxygen, nitrogen, and carbon dioxide in aqueous alcohol solutions. Journal of Chemical and Engineering Data, 20(1): p. 41-46.

24. Benson, B.B. and Krause, 1976, D., Empirical laws for dilute aqueous solutions of non-polar gases. Journal of Chemical Physics, 64(2), 689-709.

25. Cargill, R.W., 1976, Solubility of oxygen in some water-alcohol systems. Journal of the Chemical Society-Faraday Transactions I, 72, 2296-2300.

26. Broden, A. and Simonson, R., 1978, Solubility of oxygen. Part 1. Solubility of oxygen in water at temperatures $<150^{\circ} \mathrm{C}$ and pressures $<5 \mathrm{MPa}$. Svensk Papperstidning-Nordisk Cellulosa, 81(17), 541544.

27. Cosgrove, B.A. and Walkley, J., 1981, Solubilities of gases in $\mathrm{H}_{2} \mathrm{O}$ and $\mathrm{H}_{2} \mathrm{O}$. Journal of Chromatography, 216(OCT), 161-167.

28. Rettich, T.R., Battino, R. and Wilhelm, E., 2000, Solubility of gases in liquids. 22. High-precision determination of Henry's law constants of oxygen in liquid water from $\mathrm{T}=274 \mathrm{~K}$ to $\mathrm{T}=328 \mathrm{~K}$. Journal of Chemical Thermodynamics, 32(9), 1145-1156.

29. Tan, Z.Q., Gao, G.-H., Yu, Y.-X. and Gu, C., 2001, Solubility of oxygen in aqueous sodium carbonate solution at pressures up to $10 \mathrm{MPa}$. Fluid Phase Equilibria, 180(1-2), 375-382.

30. Millero, F.J., Huang, F. and Laferiere, A.L., 2002, The solubility of oxygen in the major sea salts and their mixtures at 25 degrees C. Geochimica Et Cosmochimica Acta, 66(13), 2349-2359.

31. Millero, F.J., Huang, F. and Laferiere, A.L., 2002, Solubility of oxygen in the major sea salts as a function of concentration and temperature. Marine Chemistry, 78(4), 217-230.

32. Millero, F.J. and Huang, F., 2003, Solubility of oxygen in aqueous solutions of $\mathrm{KCl}, \mathrm{K} 2 \mathrm{SO} 4$, and $\mathrm{CaCl} 2$ as a function of concentration and temperature. Journal of Chemical and Engineering Data, 48(4), 10501054.

33. Lannung, A., 1930, The solubilities of helium, neon and argon in water and some organic solvents. Journal of the American Chemical Society, 52, 68-80.

34. Morrison, T.J. and Johnstone, N.B., 1954, Solubilities of the inert gases in water. Journal of the Chemical Society, October, 3441-3446.

35. Murray, C.N. and Riley, J.P., 1970, Solubility of gases in distilled water and seawater. III. Argon. Deep-Sea Research, 17(1), 203-209.

36. Weiss, R.F., 1971, Effect of salinity on solubility of argon in seawater. Deep-Sea Research, 18(2), 225230.

37. Smith, S.P. and Kennedy, B.M., 1983, The solubility of noble gases in water and in $\mathrm{NaCl}$ brine. Geochimica Et Cosmochimica Acta, 47(3), 503-515.

38. Krause, D. and Benson, B.B., 1989, The solubility and isotopic fractionation of gases in dilute aqueous solution. IIa. Solubilities of the noble gases. Journal of Solution Chemistry, 18(9), 823-872. 
39. Kennan, R.P. and Pollack, G.L., 1990, Pressure dependence of the solubility of nitrogen, argon, krypton, and xenon in water. Journal of Chemical Physics, 93(4), 2724-2735.

40. Rettich, T.R., Battino, R. and Wilhelm, E., 1992, Solubility of gases in liquids. 18. High-precision determination of Henry fugacities for argon in liquid water at 2 to $40^{\circ} \mathrm{C}$. Journal of Solution Chemistry, 21(9), 987-1004.

41. Just, G., 1901, Solubility of gases in organic solution agents. Zeitschrift Fur Physikalische ChemieStochiometrie Und Verwandtschaftslehre, 37(3), 342-367.

42. Winkler, L.W., 1901, Solubility of gas in water. Berichte der Deutschen Chemischen Gesellschaft, 34 , 1408-1422.

43. Power, G.G. and Stegall, H., 1970, Solubility of gases in human red blood cell ghosts. Journal of Applied Physiology, 29(2), 145-149.

44. Power, G.G., 1968, Solubility of $\mathrm{O}_{2}$ and $\mathrm{CO}$ in blood and pulmonary and placental tissue. Journal of Applied Physiology, 24(4), 468-474.

45. Jung, J., Knacke, O. and Neuschutz, D., 1971, Solubility of carbon monoxide and hydrogen in water at temperatures up to $300^{\circ} \mathrm{C}$. Chemie Ingenieur Technik, 43(3), 112-116.

46. Gillespie, P.C. and G.M. Wilson, 1980, Vapor-Liquid Equilibrium Data on Water Substitute Gas Components: $\mathrm{N}_{2}-\mathrm{H}_{2} \mathrm{O}, \mathrm{H}_{2}-\mathrm{H}_{2} \mathrm{O}, \mathrm{CO}-\mathrm{H}_{2} \mathrm{O}, \mathrm{H}_{2}-\mathrm{CO}-\mathrm{H}_{2} \mathrm{O}$ and $\mathrm{H}_{2} \mathrm{~S}-\mathrm{H}_{2} \mathrm{O}$, Gas Processors Association RR41.

47. Rettich, T.R., Battino, R. and Wilhelm, E., 1982, Solubility of gases in liquids. 15. High-precision determination of Henry coefficients for carbon monoxide in liquid water at $278 \mathrm{~K}$ to $323 \mathrm{~K}$. Berichte Der Bunsen-Gesellschaft-Physical Chemistry Chemical Physics, 86(12), 1128-1132.

48. Dake, S.B. and Chaudhari, R.V., 1985, Solubility of CO in aqueous mixtures of methanol, acetic-acid, ethanol, and propionic acid. Journal of Chemical and Engineering Data, 30(4), 400-403.

49. Rumpf, B. and Maurer, G., 1992, Solubilities of hydrogen-cyanide and sulfur dioxide in water at temperatures from 293.15 to $413.15 \mathrm{~K}$ and pressures up to $2.5 \mathrm{MPa}$. Fluid Phase Equilibria, 81(1-2), 241-260.

50. Li, H., Liu, D.Z. and Wang, F.A. 2002, Solubility of dilute $\mathrm{SO}_{2}$ in dimethyl sulfoxide. Journal of Chemical and Engineering Data, 47(4), 772-775.

51. McLauchlan, W.H., 1903, On the influence of salts on the water-solubility of sulphuric hydrogen, iodine and bromine. Zeitschrift Fur Physikalische Chemie-Stochiometrie Und Verwandtschaftslehre, 44(5), 600-633.

52. Kendall, J. and Andrews, J.C., 1921, The solubilities of acids in aqueous solutions of other acids. Journal of the American Chemical Society, 43, 1545-1560.

53. Dede, L. and Becker, T., 1926, The manipulation of sulfide precipitation through the addition of neutral salts. Zeitschrift Fur Anorganische Und Allgemeine Chemie, 152(2), 185-196.

54. Selleck, F.T., Carmichael, L.T. and Sage, B.H., 1952, Phase Behavior in the Hydrogen Sulfide-Water System. Industrial \& Engineering Chemistry, 44, 2219-2226.

55. Clarke, E.C.W. and Glew, D.N., 1971, Aqueous nonelectrolyte solutions. Part VIII. Deuterium and hydrogen sulfides solubilities in deuterium oxide and water. Canadian Journal of Chemistry, 49(5), 691698.

56. Lee, J.I. and Mather, A.E., 1977, Solubility of hydrogen sulfide in water. Berichte Der BunsenGesellschaft-Physical Chemistry Chemical Physics, 81(10), 1020-1023.

57. Douabul, A.A. and Riley, J.P., 1979, Solubility of gases in distilled water and seawater. V. Hydrogen sulphide. Deep-Sea Research Part a-Oceanographic Research Papers, 26(3), 259-268.

58. Barrett, T.J., Anderson, G.M. and Lugowski, J., 1988, The solubility of hydrogen sulfide in $0-5 \mathrm{~m} \mathrm{NaCl}$ solutions at $25-95^{\circ} \mathrm{C}$ and one atmosphere. Geochimica Et Cosmochimica Acta, 52(4), 807-811.

59. Suleimenov, O.M. and Krupp, R.E., 1994, Solubility of hydrogen sulfide in pure water and in $\mathrm{NaCl}$ solutions from 20 to $320^{\circ} \mathrm{C}$ and at saturation pressures. Geochimica Et Cosmochimica Acta, 58(11), 2433-2444.

60. Kuranov, G., Rumpf, B., Smirnova, N.A. and Maurer, G., 1996, Solubility of single gases carbon dioxide and hydrogen sulfide in aqueous solutions of $\mathrm{N}$-methyldiethanolamine in the temperature range 313-413 K at pressures up to $5 \mathrm{MPa}$. Industrial \& Engineering Chemistry Research, 35(6), 1959-1966.

61. Munder, B., Lidal, H. and Sandall, O.C., 2000, Physical solubility of hydrogen sulfide in aqueous solutions of 2-(tert-butylamino)ethanol. Journal of Chemical and Engineering Data, 45(6), 1201-1204.

62. Rinker, E.B. and Sandall, O.C., 2000, Physical solubility of hydrogen sulfide in several aqueous solvents. Canadian Journal of Chemical Engineering, 78(1), 232-236.

63. Chapoy, A., Mohammadi, A.H., Tohidi, B., Valtz, A. and Richon, D., 2005, Experimental measurement and phase behavior modeling of hydrogen sulfide-water binary system. Industrial \& Engineering Chemistry Research, 44(19), 7567-7574. 
64. Koschel, D., Coxam, J.-Y. and Majer, V., 2007, Enthalpy and solubility data of $\mathrm{H}_{2} \mathrm{~S}$ in water at conditions of interest for geological sequestration. Industrial \& Engineering Chemistry Research, 46(4), 1421-1430.

65. Claussen, W.F. and Polglase, M.F., 1952, Solubilities and Structures in Aqueous Aliphatic Hydrocarbon Solutions. Journal of the American Chemical Society, 74(19), 4817-4819.

66. Shoor, S.K., Walker, R.D. and Gubbins, K.E., 1969, Salting out of nonpolar gases in aqueous potassium hydroxide solutions. Journal of Physical Chemistry, 73(2), 312-317.

67. Yokoyama, C., Wakana, S., Kaminishi, G.-I. and Takahashi, S., 1988, Vapor liquid equilibria in the methane-diethylene glycol-water system at 298.15 and 323.15 K. Journal of Chemical and Engineering Data, 33(3), 274-276.

68. Dhima, A., de Hemptinne, J.C. and Moracchini, G., Solubility of light hydrocarbons and their mixtures in pure water under high pressure. Fluid Phase Equilibria, 1998. 145(1): p. 129-150.

69. Yang, S.O., Cho, S.H., Lee, H. and Clee, C.S., 2001, Measurement and prediction of phase equilibria for water plus methane in hydrate forming conditions. Fluid Phase Equilibria, 185(1-2), 53-63.

70. Kiepe, J., Hortsmann, S., Fischer, K. and Gmehling, J., 2003, Experimental determination and correlation of liquid density data of electrolyte mixtures containing water or methanol. Industrial \& Engineering Chemistry Research, 42(9), 2022-2029.

71. Kim, Y.S., Ryu, S.K., Yang, S.O. and Lee, C.S., 2003, Liquid water-hydrate equilibriun predictions of hydrate-containing measurements and unified phase equilibria for methane, ethane, propane, and their mixtures. Industrial \& Engineering Chemistry Research, 42(11), 2409-2414.

72. Wang, L.-K., Chen, G.-J., Han, G.-H., Guo, X.-Q. and Guo, T.-M., 2003, Experimental study on the solubility of natural gas components in water with or without hydrate inhibitor. Fluid Phase Equilibria, 207(1-2), 143-154.

73. Chapoy, A., Mohammadi, A.H., Richon, D. and Tohidi, B., 2004, Gas solubility measurement and modeling for methane-water and methane-ethane-n-butane-water systems at low temperature conditions. Fluid Phase Equilibria, 220(1), 113-121.

74. Qin, J., R.J. Rosenbauer, and Z. Duan, 2008, Experimental measurements of vapor-liquid equilibria of the $\mathrm{H}_{2} \mathrm{O}+\mathrm{CO}_{2}+\mathrm{CH}_{4}$ ternary system. Journal of Chemical and Engineering Data, 53(6), 1246-1249.

75. Hufner, G., 1907, Investigations on the absorption of nitrogen-gas and hydrogen through watery solutions. Zeitschrift Fur Physikalische Chemie-Stochiometrie Und Verwandtschaftslehre, 57(5), 611625.

76. Findlay, A. and Shen, B., 1912, The Influence of Colloids and Fine Suspensions on the Solublity of Gases in Water. Part II. Solubility of Carbon Dioxide and of Hydrogen. Journal of the Chemical Society, 101, 1459-1468.

77. Wiebe, R., Gaddy, V.L. and Heins, C., 1932, Solubility of hydrogen in water at 25 degrees C. 25 to 1000 atmospheres. Industrial and Engineering Chemistry, 24, 823-825.

78. Wiebe, R. and Gaddy, V.L., 1934, The solubility of hydrogen in water at 0, 50, 75 and 100(o) from 25 to 1000 atmospheres. Journal of the American Chemical Society, 56, 76-79.

79. Ruetschi, P. and Amilie, R.F., 1966, Solubility of hydrogen in potassium hydroxide and sulfuric acid. Salting out and hydration. Journal of Physical Chemistry, 70(3), 718-723.

80. Longo, L.D., Delivoria-Papadopoulos, M., Power, G.G., Hill, E.P. and Forster, R.E., 1970, Diffusion and equilibration of inert gases between maternal and fetal placental capillaries. American Journal of Physiology, 219(3), 561-569.

81. Crozier, T.E. and Yamamoto, S., 1974, Solubility of hydrogen in water, seawater, and NaCl solutions. Journal of Chemical and Engineering Data, 19(3), 242-244.

82. Gordon, L.I., Cohen, Y. and Standley, D.R., 1977, Solubility of molecular hydrogen in seawater. DeepSea Research, 24(10), 937-941.

83. Cargill, R.W., 1978, Solubility of helium and hydrogen in some water and alcohol systems. Journal of the Chemical Society-Faraday Transactions I, 74, 1444-1456.

84. Choudhary, V.R., Parande, M.G. and Brahme, P.H., 1982, Simple apparatus for measuring solubility of gases at high pressures. Industrial \& Engineering Chemistry Fundamentals, 21(4), 472-474.

85. Alvarez, J., Crovetto, R. and Fernandez-Prini, R., 1988, The dissolution of $\mathrm{N}_{2}$ and of $\mathrm{H}_{2}$ in water from room temperature to $640 \mathrm{~K}$. Berichte Der Bunsen-Gesellschaft-Physical Chemistry Chemical Physics, 92(8), 935-940.

86. Kling, G. and Maurer, G., 1991, Solubility of hydrogen in aqueous ethanolamine solutions at temperatures between $323 \mathrm{~K}$ and $423 \mathrm{~K}$. Journal of Chemical and Engineering Data, 36(4), 390-394. 

Table 12: PR-CPA parameters for pure water (Hajiw et al., 2015)

\begin{tabular}{|c|c|c|c|c|c|c|c|c|}
\hline & $\begin{array}{c}\mathbf{a}_{0} \\
{\left[\text { bar. } \mathrm{L}^{2} \cdot \mathrm{mol}^{-2}\right]}\end{array}$ & $\begin{array}{c}\text { b } \\
{\left[\mathbf{L} . \mathrm{mol}^{-1}\right]}\end{array}$ & $\mathrm{C}_{1}$ & $\begin{array}{c}\varepsilon \\
{\left[\text { bar.L.mol }{ }^{-1} \text { ] }\right.}\end{array}$ & $\begin{array}{c}\beta \\
{\left[10^{3}\right]}\end{array}$ & $\begin{array}{c}\text { Temperature } \\
\text { range }[\mathrm{K}]\end{array}$ & $\begin{array}{c}\Delta \mathrm{P} \\
{[\%]}\end{array}$ & $\begin{array}{c}\Delta \rho \\
{[\%]}\end{array}$ \\
\hline Water & 2.2 & 0.015 & 0.64 & 146.4 & 68.3 & $273-643$ & 1.1 & 2.7 \\
\hline
\end{tabular}


Table 13: Group interaction parameters with water $\left(\mathrm{C}_{\mathrm{k}, \mathrm{H} 2 \mathrm{O}}, \mathrm{D}_{\mathrm{k}, \mathrm{H} 2 \mathrm{O}}\right.$ and $\left.\mathrm{E}_{\mathrm{k}, \mathrm{H} 2 \mathrm{O}}\right)$

\begin{tabular}{|c|c|c|c|}
\hline $\mathbf{k}$ & $\mathrm{C}_{\mathrm{k}, \mathrm{H} 2 \mathrm{O}} / 1^{3} \mathrm{~Pa}^{-K^{-2}}$ & $\mathrm{D}_{\mathrm{k}, \mathrm{H} 2 \mathrm{O}} / 1^{6} \mathrm{~Pa}^{-K^{-1}}$ & $\mathrm{E}_{\mathrm{k}, \mathrm{H} 2 \mathrm{O}} / 10^{9} \mathrm{~Pa}$ \\
\hline $\mathrm{CO}_{2}$ & -5.7 & 4.9 & -8.8 \\
\hline $\mathbf{N}_{2}$ & -12.3 & 10.9 & -18.5 \\
\hline $\mathbf{O}_{2}$ & -16.4 & 14.1 & -23.5 \\
\hline $\mathbf{A r}$ & -18.2 & 15.3 & -25.7 \\
\hline $\mathrm{CO}$ & 210 & -141 & 239 \\
\hline $\mathrm{SO}_{2}$ & -4.5 & 2.8 & -5.9 \\
\hline $\mathrm{H}_{2} \mathrm{~S}$ & -4.8 & 3.9 & -6.0 \\
\hline $\mathrm{CH}_{4}$ & -11.2 & 9.7 & -15.9 \\
\hline $\mathbf{H}_{2}$ & -10.5 & 9.5 & -14.7 \\
\hline
\end{tabular}


Table 14: Sources for Henry's law constants, HKF parameters for molar volume at infinite dilution, values for critical temperature and pressure, acentric factors and fitted water binary interaction parameters.

\begin{tabular}{|c|c|c|c|c|c|c|}
\hline Compound & $K_{g, i}\left(T, P^{s a t}\right)$ & $v_{i}^{\infty}\left[\mathrm{cm}^{3} \cdot \mathrm{mol}^{-}\right.$ & $\begin{array}{c}\mathbf{T}_{\mathbf{c}} \\
{[\mathbf{K}]}\end{array}$ & $\begin{array}{c}\mathbf{P}_{\mathbf{c}} \\
\text { [bar] }\end{array}$ & $\begin{array}{c}\text { Acentric } \\
\text { factor }\end{array}$ & $\boldsymbol{k}_{i, \mathrm{H}_{2} \mathrm{O}}$ \\
\hline & & & {$[1]$} & {$[1]$} & {$[1]$} & This study \\
\hline $\mathrm{CO}_{2}$ & {$[2]$} & [9] & 304.19 & 73.82 & 0.228 & 0.198 \\
\hline $\mathbf{N}_{2}$ & [3] & {$[10,11]$} & 126.10 & 33.94 & 0.040 & 0.455 \\
\hline $\mathbf{O}_{2}$ & {$[4]$} & {$[10,11]$} & 154.58 & 50.43 & 0.022 & 0.621 \\
\hline Ar & {$[3]$} & {$[10,11]$} & 150.86 & 48.98 & 0.000 & 0.590 \\
\hline $\mathrm{CO}$ & {$[3]$} & {$[10,11]$} & 132.92 & 34.99 & 0.066 & 0.266 \\
\hline $\mathrm{SO}_{2}$ & {$[5]$} & {$[10]$} & 430.75 & 78.84 & 0.245 & - \\
\hline $\mathbf{H}_{2} \mathrm{~S}$ & {$[6]$} & {$[12]$} & 373.53 & 89.63 & 0.083 & 0.151 \\
\hline $\mathrm{CH}_{4}$ & [7] & {$[11,12]$} & 190.58 & 46.04 & 0.011 & 0.507 \\
\hline $\mathbf{H}_{2}$ & [8] & [10] & 33.18 & 13.13 & -0.220 & 0.529 \\
\hline
\end{tabular}

1. Yaws, C.L., 1999, Chemical Properties Handbook: Physical, Thermodynamical, Environmental, Transport, Safety and Health Related Properties for Organic and Inorganic Chemicals, New-York: McGaw-Hill.

2. Duan, Z.H. and Sun, R., 2003, An improved model calculating $\mathrm{CO}_{2}$ solubility in pure water and aqueous $\mathrm{NaCl}$ solutions from 273 to $533 \mathrm{~K}$ and from 0 to 2000 bar. Chemical Geology, 193(3-4), 257271.

3. Fernandez-Prini, R., Alvarez, J.L. and Harvey, A.H., 2003, Henry's constants and vapor-liquid distribution constants for gaseous solutes in $\mathrm{H}_{2} \mathrm{O}$ and $\mathrm{D}_{2} \mathrm{O}$ at high temperatures. Journal of Physical and Chemical Reference Data, 32(2), 903-916.

4. Ji, X.Y., Lu, X.H. and Yan, J.Y., 2004, Phase equilibria for the oxygen-water system up to elevated temperatures and pressures. Fluid Phase Equilibria, 222, 39-47.

5. Chapoy, A., Haghighi, H. and Tohidi, B., 2008, Development of a Henry's constant correlation and solubility measurements of n-pentane, i-pentane, cyclopentane, n-hexane, and toluene in water. Journal of Chemical Thermodynamics, 40(6), 1030-1037.

6. Zirrahi, M., Azin, R., Hassanzadeh, H. and Moshfeghian, M., 2012, Mutual solubility of $\mathrm{CH}_{4}, \mathrm{CO}_{2}$, $\mathrm{H}_{2} \mathrm{~S}$, and their mixtures in brine under subsurface disposal conditions. Fluid Phase Equilibria, , 324, 8093. 
7. Duan, Z. and Mao, S., 2006, A thermodynamic model for calculating methane solubility, density and gas phase composition of methane-bearing aqueous fluids from 273 to $523 \mathrm{~K}$ and from 1 to 2000 bar. Geochimica Et Cosmochimica Acta, 70(13), 3369-3386.

8. Harvey, A.H., 1996, Semi empirical Correlation for Henry's Constants over Large Temperature Ranges. AIChE Journal, 42(5), 1491-1494.

9. Appelo, C.A.J., Parkhurst D.L. and Post V.E.A., 2014, Equations for calculating hydrogeochemical reactions of minerals and gases such as at high pressures and temperatures. Geochimica Et Cosmochimica Acta, 125, 49-67.

10. Shock, E.L., Helgeson, H.C. and Sverjensky, D.A., 1989, Calculation of the thermodynamic and transport properties of aqueous species at high pressures and temperatures: Standard partial molal properties of inorganic neutral species. Geochimica Et Cosmochimica Acta, 53, 2157-2183.

11. Schulte, M.D., Shock, E.L. and Wood, R.H., 2001, The temperature dependence of the standard-state thermodynamic properties of aqueous nonelectrolytes. Geochimica Et Cosmochimica Acta, 65(21), 3919-3930.

12. Springer, R.D., Wang, P. and Anderko, A., 2015, Modeling the properties of $\mathrm{H}_{2} \mathrm{~S} / \mathrm{CO}_{2} / \mathrm{salt} / \mathrm{water}$ systems in wide ranges of temperature and pressure. SPE Journal, 1120-1134.

13. Shock, E.L. and Helgeson, H.C., 1990, Calculation of the thermodynamic and transport properties of aqueous species at high pressures and temperatures: Standard partial molal properties of organic species. Geochimica Et Cosmochimica Acta, 54, 915-945. 
Table 15: AAE (Absolute Average Error) and AAD (Absolute Average Deviation)) between experimental data and predictions

\begin{tabular}{|c|c|c|c|c|c|c|c|c|c|}
\hline & \multicolumn{2}{|c|}{$\begin{array}{c}\text { GC-PR-CPA } \\
\text { EoS }\end{array}$} & \multicolumn{2}{|c|}{ E-PPR78 EoS } & \multicolumn{2}{|c|}{$\begin{array}{c}\text { Geochemical } \\
\text { model }\end{array}$} & \multicolumn{2}{|c|}{ Duan } & \multirow{2}{*}{$\begin{array}{c}\text { Number of } \\
\text { experimental } \\
\text { points }\end{array}$} \\
\hline & $\begin{array}{c}\text { AAE } \\
\text { (mole } \\
\text { fraction) }\end{array}$ & $\begin{array}{l}\text { AAD } \\
(\%)\end{array}$ & $\begin{array}{c}\text { AAE } \\
\text { (mole } \\
\text { fraction) }\end{array}$ & $\begin{array}{l}\text { AAD } \\
(\%)\end{array}$ & $\begin{array}{c}\text { AAE } \\
\text { (mole } \\
\text { fraction) }\end{array}$ & $\begin{array}{l}\text { AAD } \\
(\%)\end{array}$ & $\begin{array}{c}\text { AAE } \\
\text { (mole } \\
\text { fraction) }\end{array}$ & $\begin{array}{l}\text { AAD } \\
(\%)\end{array}$ & \\
\hline $\mathrm{x} \mathrm{CO}_{2}$ & $1.10^{-3}$ & 8.9 & $1.10^{-3}$ & 6.3 & $1.10^{-3}$ & 5.6 & $6.10^{-4}$ & 4.1 & 1803 \\
\hline y $\mathrm{H}_{2} \mathrm{O}$ & $7.10^{-3}$ & 13.2 & $8.10^{-3}$ & 14.3 & $8.10^{-3}$ & 9.0 & $2.10^{-2}$ & 28.5 & 413 \\
\hline $\mathbf{x N _ { 2 }}$ & $5.10^{-5}$ & 3.7 & $6.10^{-4}$ & 84.0 & $5.10^{-5}$ & 3.9 & $4.10^{-5}$ & 3.8 & 561 \\
\hline y $\mathrm{H}_{2} \mathrm{O}$ & $2.10^{-3}$ & 9.8 & $2.10^{-3}$ & 4.7 & $3.10^{-3}$ & 5.3 & $3.10^{-3}$ & 5.2 & 163 \\
\hline $\mathrm{xO_{2 }}$ & $2.10^{-5}$ & 4.4 & $2.10^{-4}$ & 71.2 & $3.10^{-5}$ & 4.5 & $3.10^{-5}$ & 4.8 & 835 \\
\hline y $\mathrm{H}_{2} \mathrm{O}$ & $2.10^{-4}$ & 13.0 & $1.10^{-3}$ & 69.1 & $1.10^{-5}$ & 0.6 & - & - & 14 \\
\hline $\mathbf{x} \mathbf{A r}$ & $7.10^{-6}$ & 2.6 & - & - & $1.10^{-5}$ & 2.6 & - & - & 296 \\
\hline y $\mathrm{H}_{2} \mathrm{O}$ & $4.10^{-4}$ & 8.9 & - & - & $1.10^{-3}$ & 1.3 & - & - & 28 \\
\hline x CO & $4.10^{-5}$ & 9.6 & - & - & $5.10^{-5}$ & 9.8 & - & - & 187 \\
\hline y $\mathrm{H}_{2} \mathrm{O}$ & $3.10^{-3}$ & 1.9 & - & - & $7.10^{-3}$ & 3.0 & - & - & 17 \\
\hline $\mathrm{x} \mathrm{SO}_{2}$ & $2.10^{-3}$ & 17.6 & $3.10^{-3}$ & 14.7 & $2.10^{-3}$ & 16.7 & & & 393 \\
\hline$x \mathrm{CH}_{4}$ & $1.10^{-4}$ & 6.8 & $5.10^{-4}$ & 10.2 & $1.10^{-4}$ & 6.7 & $1.10^{-4}$ & 6.3 & 678 \\
\hline y $\mathrm{H}_{2} \mathrm{O}$ & $2.10^{-3}$ & 15.9 & $2.10^{-3}$ & 6.5 & $2.10^{-3}$ & 6.2 & $1.10^{-3}$ & 5.3 & 319 \\
\hline$\times \mathrm{H}_{2} \mathrm{~S}$ & $1.10^{-3}$ & 6.1 & $6.10^{-4}$ & 3.4 & $3.10^{-3}$ & 9.9 & $7.10^{-4}$ & 3.5 & 704 \\
\hline y $\mathrm{H}_{2} \mathrm{O}$ & $6.10^{-3}$ & 11.6 & $6.10^{-3}$ & 8.1 & $1.10^{-2}$ & 7.1 & - & - & 183 \\
\hline$\times \mathrm{H}_{2}$ & $4.10^{-4}$ & 7.4 & $9.10^{-2}$ & $>100$ & $6.10^{-4}$ & 10.5 & & & 571 \\
\hline y $\mathbf{H}_{2} \mathrm{O}$ & $3.10^{-3}$ & 5.4 & $6.10^{-3}$ & 21.4 & $8.10^{-3}$ & 3.3 & & & 17 \\
\hline
\end{tabular}


Table 16: AAE (Absolute Average Error) and AAD (Absolute Average Deviation)) between experimental data and predictions at limited pressure conditions

\begin{tabular}{|c|c|c|c|c|c|c|c|c|c|}
\hline & \multicolumn{2}{|c|}{$\begin{array}{c}\text { GC-PR-CPA } \\
\text { EoS }\end{array}$} & \multicolumn{2}{|c|}{ E-PPR78 EoS } & \multicolumn{2}{|c|}{$\begin{array}{c}\text { Geochemical } \\
\text { model }\end{array}$} & \multicolumn{2}{|c|}{ Duan } & \multirow{2}{*}{$\begin{array}{c}\text { Number of } \\
\text { experimental } \\
\text { points }\end{array}$} \\
\hline & $\begin{array}{c}\text { AAE } \\
\text { (mole } \\
\text { fraction) }\end{array}$ & $\begin{array}{l}\text { AAD } \\
(\%)\end{array}$ & $\begin{array}{c}\text { AAE } \\
\text { (mole } \\
\text { fraction) }\end{array}$ & $\begin{array}{l}\text { AAD } \\
(\%)\end{array}$ & $\begin{array}{c}\text { AAE } \\
\text { (mole } \\
\text { fraction) }\end{array}$ & $\begin{array}{l}\text { AAD } \\
(\%)\end{array}$ & $\begin{array}{c}\text { AAE } \\
\text { (mole } \\
\text { fraction) }\end{array}$ & $\begin{array}{l}\text { AAD } \\
(\%)\end{array}$ & \\
\hline $\mathrm{x} \mathrm{CO}_{2}$ & $8.10^{-4}$ & 6.3 & $8.10^{-4}$ & 5.5 & $6.10^{-4}$ & 4.1 & $5.10^{-4}$ & 4.0 & 725 \\
\hline y $\mathbf{H}_{2} \mathrm{O}$ & $4.10^{-3}$ & 13.5 & $4.10^{-3}$ & 14.9 & $3.10^{-3}$ & 9.4 & $8.10^{-3}$ & 24.7 & 235 \\
\hline $\mathbf{x N _ { 2 }}$ & $6.10^{-5}$ & 4.7 & $8.10^{-4}$ & 74.4 & $7.10^{-4}$ & 5.1 & $7.10^{-5}$ & 5.4 & 152 \\
\hline y $\mathrm{H}_{2} \mathrm{O}$ & $1.10^{-3}$ & 7.6 & $6.10^{-4}$ & 4.9 & $3.10^{-3}$ & 5.1 & $9.10^{-4}$ & 5.9 & 59 \\
\hline $\mathrm{x \textrm {O } _ { 2 }}$ & $5.10^{-5}$ & 5.6 & $5.10^{-4}$ & 52.9 & $7.10^{-5}$ & 8.2 & $5.10^{-5}$ & 6.6 & 127 \\
\hline y $\mathrm{H}_{2} \mathrm{O}$ & $3.10^{-4}$ & 10.1 & $2.10^{-3}$ & 60.0 & $2.10^{-5}$ & 0.6 & - & - & 9 \\
\hline $\mathbf{x} \mathbf{A r}$ & $6.10^{-5}$ & 3.2 & - & - & $9.10^{-5}$ & 4.4 & - & - & 11 \\
\hline y $\mathbf{H}_{2} \mathrm{O}$ & $4.10^{-4}$ & 3.5 & - & - & $9.10^{-5}$ & 0.5 & - & - & 14 \\
\hline x CO & $5.10^{-5}$ & 11.2 & - & - & $6.10^{-5}$ & 12.5 & - & - & 97 \\
\hline y $\mathbf{H}_{2} \mathrm{O}$ & $5.10^{-4}$ & 1.8 & - & - & $4.10^{-4}$ & 1.5 & - & - & 12 \\
\hline $\mathbf{x} \mathrm{SO}_{2}$ & $2.10^{-3}$ & 10.6 & $1.10^{-2}$ & 27.6 & $6.10^{-3}$ & 25.9 & & & 30 \\
\hline$x \mathrm{CH}_{4}$ & $1.10^{-4}$ & 7.4 & $2.10^{-4}$ & 10.0 & $1.10^{-4}$ & 7.6 & $1.10^{-4}$ & 7.6 & 430 \\
\hline y $\mathbf{H}_{2} \mathrm{O}$ & $2.10^{-3}$ & 15.6 & $1.10^{-3}$ & 5.8 & $2.10^{-3}$ & 5.5 & $1.10^{-3}$ & 5.2 & 270 \\
\hline$\times \mathrm{H}_{2} \mathrm{~S}$ & $2.10^{-3}$ & 7.7 & $8.10^{-4}$ & 3.7 & $3.10^{-3}$ & 13.9 & $1.10^{-3}$ & 3.8 & 450 \\
\hline y $\mathbf{H}_{2} \mathrm{O}$ & $8.10^{-3}$ & 15.4 & $9.10^{-3}$ & 10.6 & $1.10^{-2}$ & 9.2 & - & - & 131 \\
\hline $\mathbf{x H _ { 2 }}$ & $1.10^{-4}$ & 6.8 & $1.10^{-1}$ & $>100$ & $2.10^{-4}$ & 10.4 & - & - & 298 \\
\hline y $\mathbf{H}_{2} \mathbf{O}$ & $3.10^{-3}$ & 5.7 & $6.10^{-3}$ & 23.4 & $8.10^{-3}$ & 3.3 & - & - & 15 \\
\hline
\end{tabular}


Table 17: Deviations (AAD \%) between experimental data and predictions for $\mathrm{CO}_{2}-\mathrm{H}_{2} \mathrm{O}$ and $\mathrm{SO}_{2}-\mathrm{H}_{2} \mathrm{O}$ binary systems

\begin{tabular}{|c|c|c|c|c|c|}
\hline System & Solubility & $\begin{array}{c}\text { GC-PR- } \\
\text { CPA EoS } \\
(\%)\end{array}$ & $\begin{array}{l}\text { E-PPR78 } \\
\operatorname{EoS}(\%)\end{array}$ & $\begin{array}{c}\text { Geochemical } \\
\text { model }(\%)\end{array}$ & $\begin{array}{c}\text { Duan and } \\
\text { Sun [101] } \\
(\%)\end{array}$ \\
\hline \multirow[b]{2}{*}{$\mathrm{CO}_{2}-\mathrm{H}_{2} \mathrm{O}$} & $\begin{array}{c}\mathrm{x} \mathrm{CO}_{2} \text { (Hou et al., } \\
\text { 2013) }\end{array}$ & 3.0 & 5.2 & 5.0 & 5.6 \\
\hline & $\begin{array}{c}\mathrm{y} \mathrm{H}_{2} \mathrm{O} \\
\text { (Hou et al., 2013; } \\
\text { Caumon et al., 2016) }\end{array}$ & 15.4 & 15.1 & 14.9 & 15.8 \\
\hline $\mathrm{SO}_{2}-\mathrm{H}_{2} \mathrm{O}$ & $\begin{array}{c}\text { x SO}_{2} \text { (Hou et al., } \\
2013 \text { ) }\end{array}$ & 5.5 & 24.6 & 22.3 & - \\
\hline
\end{tabular}


Table 18: Deviations (AAD \%) between experimental data and predictions for ternary systems

\begin{tabular}{|c|c|c|c|}
\hline System & Solubility & GC-PR-CPA EoS (\%) & E-PPR78 EoS (\%) \\
\hline \multirow{2}{*}{$\begin{array}{c}\mathrm{CO}_{2}-\mathrm{N}_{2}-\mathrm{H}_{2} \mathrm{O} \text { (Liu et } \\
\text { al., 2012) }\end{array}$} & $\mathrm{x} \mathrm{CO}_{2}$ & 7.1 & 3.6 \\
\hline & $\mathrm{x} \mathrm{N}_{2}$ & 18.6 & 84.4 \\
\hline \multirow{2}{*}{$\begin{array}{c}\mathrm{CO}_{2}-\mathrm{CH}_{4}-\mathrm{H}_{2} \mathrm{O}(\mathrm{Qin} \\
\text { et al., 2008) }\end{array}$} & $\mathrm{x} \mathrm{CO}_{2}$ & 11.1 & 6.9 \\
\hline & $\mathrm{x} \mathrm{CH}_{4}$ & 8.1 & 6.1 \\
\hline \multirow{3}{*}{$\mathrm{CO}_{2}-\mathrm{CH}_{4}-\mathrm{H}_{2} \mathrm{O}$} & $\begin{array}{c}\mathrm{y} \mathrm{H}_{2} \mathrm{O} \text { (Chapoy et al., } \\
\text { 2016) }\end{array}$ & 4.0 & 1.8 \\
\hline & y $\mathrm{H}_{2} \mathrm{O}$ (Qin et al., 2008) & 45.7 & 36.7 \\
\hline & $\begin{array}{c}\text { y } \mathrm{H}_{2} \mathrm{O} \text { (Al Ghafri et al., } \\
\text { 2014) }\end{array}$ & 32.8 & 32.3 \\
\hline \multirow{4}{*}{$\begin{array}{c}\mathrm{CO}_{2}-\mathrm{CH}_{4}-\mathrm{H}_{2} \mathrm{~S}-\mathrm{H}_{2} \mathrm{O} \\
\text { (Robinson et al., } \\
1982 \text { ) }\end{array}$} & $\mathrm{x} \mathrm{CO}_{2}$ & 3.0 & 2.9 \\
\hline & $\mathrm{x} \mathrm{CH}_{4}$ & 2.0 & 12.6 \\
\hline & $\mathrm{x} \mathrm{H}_{2} \mathrm{~S}$ & 7.1 & 12.6 \\
\hline & $\mathrm{y} \mathrm{H}_{2} \mathrm{O}$ & 14.2 & 2.7 \\
\hline
\end{tabular}

